\title{
A Review of the Historical Background, Needs, Design approaches and Future Challenges in Groundwater Level Monitoring Networks
}

\author{
Chandan Kumar Singh* and Yashwant B. Katpatal
}

Sierra Nevada Research Institute, University of California, 5200 Lake Rd, Merced, CA 95343, USA

Received 16 September 2019; Accepted 12 March 2020

\begin{abstract}
A Groundwater Level Monitoring Network (GWLMN) is the most direct and important source of data for monitoring hydrogeological variations in aquifers. Extensive research has been conducted on surface water and groundwater quality monitoring networks, but less consideration has been given to GWLMNs. Due to a lack of funding and negligence, GWLMNs are either limited or not enough for decision-making purposes. This review initially summarizes the historical developments of GWLMNs in different countries and then, the needs, design approaches, recent developments and future challenges are articulated comprehensively. The needs for GWLMNs generally include information on (1) spatiotemporal assessments (2) climate change (3) land subsidence and (4) Groundwater and Surface Water (GW-SW) interactions. This article reviews the evolution of various design approaches utilized in the past, with respect to their strengths and weaknesses such as geostatistical, entropy, Multi-Criteria Analysis (MCA), and others. The present and shifting trends in research on the design of groundwater monitoring networks are discussed. In addition, developments, challenges and opportunities in utilizing recent remote sensing products are briefly outlined. Future research scopes include the need to develop systematic and continuous GWLMNs in many developing countries, the conjunctive use of field and remotely sensed data, such as NASA's Gravity Recovery and Climate Change Experiment (GRACE) data to design GWLMNs, and the design of an integrated monitoring network to study the link between climate and groundwater level changes to better and more efficiently design GWLMNs.
\end{abstract}

Keywords: Groundwater; Monitoring network; Climate change; Satellite data

\section{Introduction}

Information collection through monitoring network is widely used all over the world for collecting data on precipitation, surface water quality, stream flow, groundwater quality, and groundwater levels [1]. Globally, groundwater provides $42 \%$ of water for agricultural use, $35 \%$ for domestic water supply, and $23 \%$ for industrial water supply [2]. If the rising trends of groundwater use continue in the future, then most of the aquifers will be under stress, leading to overexploitation of groundwater resources. The adverse effects of overexploitation can be foreseen in the forms of groundwater level decline, reduction in groundwater storage, land subsidence, groundwater quality deterioration, etc. [3]. Over the past several decades, extensive research has been conducted to understand the complex groundwater resource systems. Still, the designing, planning, and management of groundwater resources are far from appropriate. Systematic, continuous, and long-term field data are essential to formulate and develop efficient groundwater models for better understanding, predicting, and forecasting groundwater resource data [4].

Information collected from water monitoring networks is the first step in the direction of effective water resource management. The basic design principle of any monitoring network is to select an appropriate location, number, and frequency of samples. In many parts of the world, water-

\footnotetext{
*E-mail address: csingh6@ucmerced.edu

ISSN: 1791-2377 @ 2020 School of Science, IHU. All rights reserved.

doi:10.25103/jestr. 132.18
}

monitoring networks are either limited or not adequately designed [6]. In general, the number of monitoring networks is decreasing due to economic constraints and changes in monitoring policies [7]. Hence, to ensure appropriate sampling locations and sample numbers, it is vital to redesign the monitoring network.

A review of the recent literature indicated that many investigations have been conducted to examine and design surface water monitoring networks. For example, the first precipitation and stream flow networks were designed in 1939 and 1954, respectively, using statistical techniques [8]. Statistical and optimization-based algorithms are commonly used to design monitoring networks. A considerable amount of research on groundwater quality networks was also reviewed and reported by Loaiciga et al. [9] and others (Harmancioglu et al. [10]; Zhang et al. [11]; Ammar et al.[12]). However, the design of groundwater level monitoring networks has been given less consideration than other monitoring networks. Hence, the present study provides brief insight and a summary of the previous research outcomes and the developments related to the GWLMN.

The objectives of this paper are:

(1) To understand the historical background of the GWLMN in different parts of the world. The background information consists of monitoring objectives, past records, present scenarios, and monitoring frequencies.

(2) To classify the needs and purposes of the GWLMN. The general objectives for establishing the GWLMN include quantifying the spatiotemporal changes in groundwater, GWSW interactions, climate change, and land subsidence. 
(3) To compare and understand different GWLMN approaches. Comparison of approaches involves identifying the strengths and weaknesses of different approaches. The basis of comparison was design principles, input parameters, monitoring objectives, frequency of monitoring etc.

(4) To understand the recent technological developments of GWLMN over the past several decades and identify future opportunities. Developments in satellite data collection, such as GRACE and Moderate Resolution Imaging Spectroradiometer (MODIS), geoinformatics technology, and airborne techniques are investigated in relation to groundwater measurements.

\section{Historical background and present status of the GWLMN}

In the present study, peer-reviewed journals related to theoretical suggestions and design details for the groundwater monitoring network were investigated. It was observed during literature survey that there are a few peer-reviewed journal articles related to the groundwater level monitoring network. This indicates that most of the guidelines and design principles have not appeared in peer-reviewed journals and appears only in national reports of the counties or agencies. In addition, the websites of many countries are either not accessible or sufficient details are missing. Hence, based on the available details related to groundwater monitoring, select information is summarized in Table 1 and discussed in subsequent paragraphs.

Table 1. Inventory of groundwater level monitoring networks in selected countries

\begin{tabular}{|c|c|c|c|c|c|c|c|c|c|c|}
\hline \multirow[t]{2}{*}{ Country } & \multirow[t]{2}{*}{$\begin{array}{l}\text { Area } \\
\left(\mathbf{k m}^{2}\right)\end{array}$} & \multirow{2}{*}{$\begin{array}{l}\text { Numb } \\
\text { er of } \\
\text { OWs }\end{array}$} & \multirow{2}{*}{$\begin{array}{l}\text { Monitori } \\
\text { ng } \\
\text { started }\end{array}$} & \multirow[t]{2}{*}{$\begin{array}{l}\text { Monitoring } \\
\text { objectives }\end{array}$} & \multirow{2}{*}{$\begin{array}{c}\text { Frequen } \\
\text { cy of } \\
\text { monitori } \\
\text { ng }\end{array}$} & \multicolumn{2}{|c|}{$\begin{array}{c}\text { Design } \\
\text { approaches }\end{array}$} & \multirow{2}{*}{\begin{tabular}{|c|} 
Monitoring \\
organization/agen \\
cies
\end{tabular}} & \multirow[t]{2}{*}{ Remark } & \multirow[t]{2}{*}{ Source } \\
\hline & & & & & & \begin{tabular}{|l|} 
Hydro- \\
geolog \\
ic \\
\end{tabular} & $\begin{array}{l}\text { Statistic } \\
\text { al }\end{array}$ & & & \\
\hline India & \begin{tabular}{|l|}
$3,287,2$ \\
63
\end{tabular} & 22,339 & 1969 & $\begin{array}{l}\text { Quantitative } \\
\text { assessment }\end{array}$ & Quarterly & $\checkmark$ & $x$ & $\begin{array}{l}\text { Central Ground } \\
\text { Water Board }\end{array}$ & \begin{tabular}{|l|} 
Priority has \\
been given \\
to observe \\
the response \\
of GWL \\
changes due \\
to natural \\
and \\
anthropogen \\
ic activities
\end{tabular} & $\begin{array}{l}{[136],[13} \\
7]\end{array}$ \\
\hline China & $\begin{array}{l}9,596,9 \\
60\end{array}$ & 24,417 & 1950 & $\begin{array}{l}\text { Quantitative } \\
\text { assessment } \\
\text { (at national, } \\
\text { provincial } \\
\text { and local } \\
\text { level) }\end{array}$ & $\begin{array}{l}3 \text { times in } \\
\text { a month }\end{array}$ & $\checkmark$ & $\checkmark$ & $\begin{array}{l}\text { National } \\
\text { groundwater } \\
\text { monitoring center }\end{array}$ & $\begin{array}{l}\text { Additional } \\
20,455 \text { OWs } \\
\text { is planned } \\
\text { to modify } \\
\text { the existing } \\
\text { network }\end{array}$ & {$[138]$} \\
\hline $\begin{array}{l}\text { United } \\
\text { States }\end{array}$ & $\begin{array}{l}9,833,5 \\
20\end{array}$ & 20,000 & $\begin{array}{l}1923 \\
\text { (specific } \\
\text { area), } \\
1960 \\
\text { (Nation- } \\
\text { wide) }\end{array}$ & $\begin{array}{l}\text { Quantitative } \\
\text { assessment }\end{array}$ & $\begin{array}{l}\text { Twice in } \\
\text { a year }\end{array}$ & $\checkmark$ & $\checkmark$ & $\begin{array}{l}\text { United States } \\
\text { Geological Survey }\end{array}$ & \begin{tabular}{|l|} 
More \\
importance \\
has been \\
given to the \\
link \\
between \\
monitoring \\
and \\
hydrologic \\
research
\end{tabular} & [139] \\
\hline Pakistan & 881,913 & 840 & 2003 & $\begin{array}{l}\text { Quantitative } \\
\text { assessment }\end{array}$ & $\begin{array}{l}\text { Twice in } \\
\text { a year }\end{array}$ & $\checkmark$ & $x$ & $\begin{array}{l}\text { Water and } \\
\text { sanitation agency }\end{array}$ & $\begin{array}{l}\text { Long-term } \\
\text { expansion } \\
\text { of } \\
\text { monitoring } \\
\text { network is } \\
\text { needed }\end{array}$ & [140] \\
\hline Iran & $\begin{array}{l}1,648,1 \\
95\end{array}$ & 1346 & 1984 & $\begin{array}{l}\text { Quantitative } \\
\text { assessment }\end{array}$ & Monthly & $\checkmark$ & $\checkmark$ & $\begin{array}{l}\text { Water Affairs } \\
\text { Department, } \\
\text { Ministry of } \\
\text { Energy. }\end{array}$ & \begin{tabular}{|l|} 
Insufficient \\
groundwater \\
monitoring \\
wells
\end{tabular} & $\begin{array}{l}{[141] ;} \\
{[142]}\end{array}$ \\
\hline $\begin{array}{l}\text { Banglade } \\
\text { sh }\end{array}$ & 130,170 & 3000 & 1981 & $\begin{array}{l}\text { Quantitative } \\
\text { assessment }\end{array}$ & Yearly & $\checkmark$ & $x$ & $\begin{array}{l}\text { Bangladesh Water } \\
\text { Development } \\
\text { Board }\end{array}$ & $\begin{array}{l}\text { The } \\
\text { frequency of } \\
\text { monitoring } \\
\text { is required } \\
\text { to improve }\end{array}$ & [143] \\
\hline Mexico & $\begin{array}{l}1,972,5 \\
50\end{array}$ & 12000 & 1974 & $\begin{array}{l}\text { Quantitative } \\
\text { assessment }\end{array}$ & NA & $\checkmark$ & $\checkmark$ & $\begin{array}{l}\text { National Water } \\
\text { Commission }\end{array}$ & $\begin{array}{l}\text { Existing } \\
\text { wells } \\
(12000) \\
\text { monitors }\end{array}$ & [145] \\
\hline
\end{tabular}




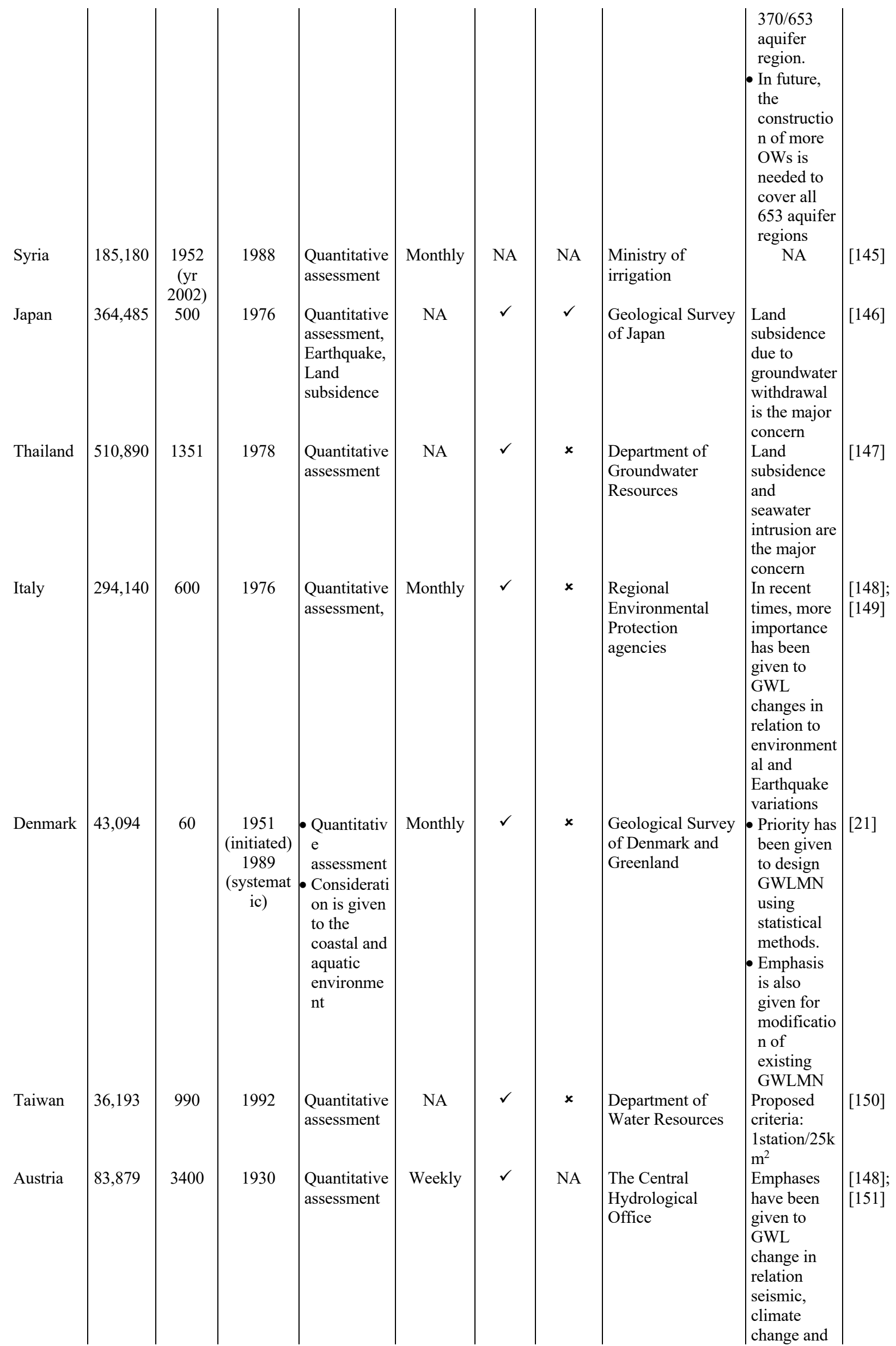




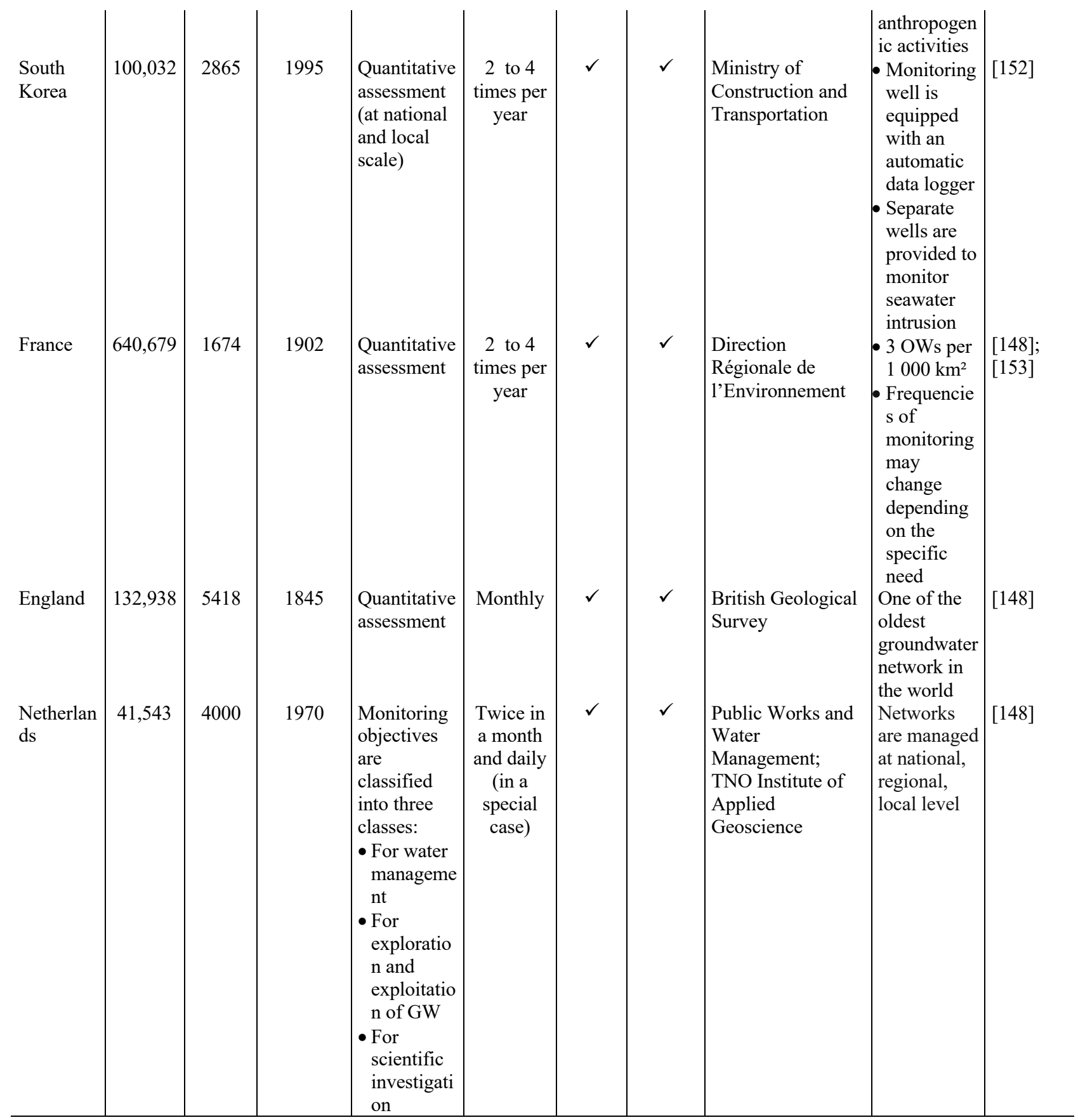

NA: Not available; OW: Observation well

Historical perspectives on the roles of the groundwater monitoring issue were provided by Peters [13] and others (Heath [14]; Hughes and Lettenmaier [15]. A report by Jousma and Roelofsen [3] and fundamental papers by Sophocleous et al. [16] and others (Olea [17]; Szidarovszky [18]; Bogardi and Bardossy [19]) provide the significance of the statistical methods used to optimize the GWLMN. Loaiciga et al. [9] categorized groundwater monitoring network design approaches in two classes (1) hydrogeologic approaches (based on hydrologic information) and (2) statistical approaches. The history of the first GWLMN (hydrogeologic approach) traces back to 1845 in England/Wales; however, the first GWLMN in France was founded in 1902, while in the USA, it began at specific locations in 1923, but the nationwide construction of monitoring networks began at the end of 1960. In European countries, groundwater level monitoring started in 19501980. Other historical details of the GWLMN are specified in
Table 1. However, the designs of these networks were initially based on quantitative and qualitative hydrologic information. The first systematic GWLMN was designed in the 1980s. In some countries, systematic groundwater monitoring networks were established after the 1980s (Table 1). However, records of groundwater monitoring networks are not available for some countries like Saudi Arabia, Turkey, Indonesia etc.

The countries mentioned in Table 2 have records of the highest groundwater abstraction rates (in $\mathrm{km}^{3} / \mathrm{yr}$ ) all over the world which includes many developing countries. Gleeson et al. [20] have estimated the global groundwater footprint and have also identified the countries with respect to their groundwater recharge and abstractions. The list includes several developing countries with a higher amount of groundwater utilizations. The present study relates to the status of groundwater monitoring networks. The drinking water supplies in countries such as Denmark (100\%), Austria (99\%), and Italy (85\%) are mostly based on groundwater 
[21]. Table 1 summarizes the details of the GWLMNs in selected countries. The countries with the highest amounts of groundwater withdrawal (Table 2), oldest monitoring records, and those that are highly dependent on groundwater were selected for examination. The examination includes the history, frequency, monitoring objectives, and design approaches of the monitoring networks. The number of observation wells and the details of the monitoring organizations of these countries are also included in Table 1. However, information related to the GWLMN in some countries (Indonesia, Turkey, Saudi Arabia, Russia, and Thailand) was missing.

Table 2. Top fifteen nations with the highest estimated groundwater withdrawal [41]*

\begin{tabular}{|c|c|c|c|c|}
\hline \multirow[t]{2}{*}{ Country } & \multirow{2}{*}{$\begin{array}{c}\text { Estimated } \\
\text { groundwater } \\
\text { withdrawal } \\
\left(\mathbf{k m}^{3} / \mathbf{y r}\right)\end{array}$} & \multicolumn{3}{|c|}{ Groundwater withdrawal (\%) } \\
\hline & & Irrigation & Domestic & Industry \\
\hline India & 251 & 89 & 9 & 2 \\
\hline China & 111.95 & 54 & 20 & 26 \\
\hline United & 111.70 & 71 & 23 & 6 \\
\hline States & & & & \\
\hline Pakistan & 64.82 & 94 & 6 & 0 \\
\hline Iran & 63.40 & 87 & 11 & 2 \\
\hline Bangladesh & 30.21 & 86 & 13 & 1 \\
\hline Mexico & 29.45 & 72 & 22 & 6 \\
\hline Saudi & 24.24 & 92 & 5 & 3 \\
\hline Arabia & & & & \\
\hline Indonesia & 14.93 & 2 & 93 & 5 \\
\hline Turkey & 13.22 & 60 & 32 & 8 \\
\hline Russia & 11.62 & 3 & 79 & 18 \\
\hline Syria & 11.29 & 90 & 5 & 5 \\
\hline Japan & 10.94 & 23 & 29 & 48 \\
\hline Thailand & 10.74 & 14 & 60 & 26 \\
\hline Italy & 10.40 & 67 & 23 & 10 \\
\hline
\end{tabular}

*This table is taken from book "Groundwater around the World: A Geographic Synopsis"

In general, it was observed that the number of observation wells within a network in different countries varies from a few hundred to thousands (Table 1). Most of these networks were designed for quantitative assessments of the groundwater basin. During a quantitative assessment, the influences of excessive withdrawals on the groundwater levels are monitored in space and time [22]. In addition, changes in groundwater levels are also attributed to several hydrological phenomena, which are becoming integral parts of the monitoring objectives. For instance, monitoring objectives also include natural and anthropogenic activities (India), earthquake variations (Japan and Italy), land subsidence (Japan), climate change (Austria, USA), and seawater intrusion (Bangladesh). However, these attributes of the monitoring objectives and priorities are limited to some select countries. The monitoring frequencies in different countries vary widely from daily, weekly, monthly, quarterly, sixmonthly to annually. These variations in frequency are directly linked to monitoring priorities. For example, in India, groundwater is monitored quarterly (January, March, May, and October) to measure the seasonal variations. Similarly, the monitoring frequencies in different countries change with monitoring priority (Table 1).

\section{Need for a GWLMN}

Groundwater level (GWL) data collection is essential for several reasons, such as to analyze the spatial and temporal variations in groundwater resources, to understand the water levels under various hydrological stresses, to determine the interaction of the GWL with surface water resources, and to understand the variations in GWL that are due to natural and human activities. In addition, systematic and long-term measurements of the GWL can enhance the understanding and facilitate effective planning and management of groundwater resources. Recent studies mentioned in the subsequent section (3.1) to (3.4) have highlighted the following factors to justify the importance and need for GWL measurements (Fig. 1).

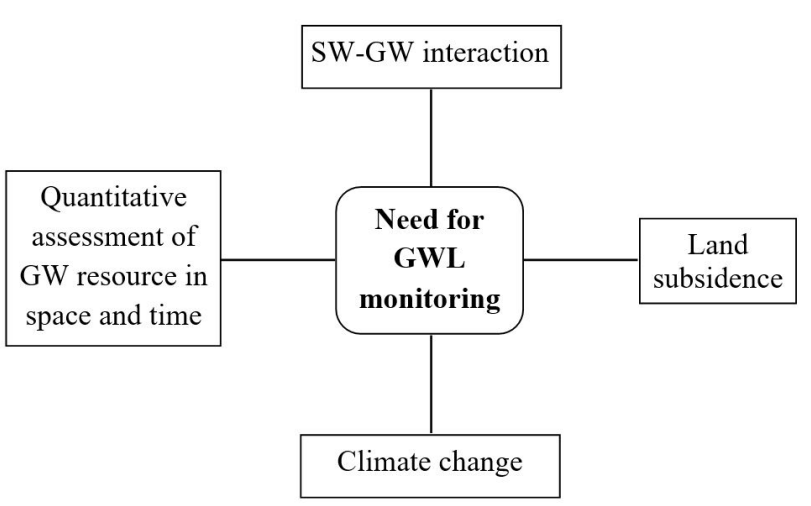

Fig. 1. Common needs for monitoring groundwater level appeared in recent literatures

\subsection{Climate change and GWLMNs}

The occurrence, movement, and storage systems of groundwater are complex phenomena, and climate change makes the measurement of these phenomena more challenging. Climate change can alter groundwater resources both directly through changes in GWL and indirectly through changes in groundwater utility (Taylor et al. [23]; Singh and Katpatal [24]; Smerdon [25]). Additionally, groundwater is very sensitive to climate change [26], and alterations of natural and anthropogenic activities such as precipitation, irrigation pattern, and land use are directly responsible for groundwater recharge.

Since 2005, investigators have adopted diverse approaches to studying the impacts of climate change on groundwater resources [25]. The vulnerability of groundwater due to a changing climate has been studied by some researchers in the past decade [27], [26], and [28]. Direct impacts of climate change have been observed on groundwater recharge [26] and GWL changes [29] and [30]. Kløve et al. [27] described the spatiotemporal monitoring and relationship between groundwater and dependent ecosystems of shallow aquifers in relation to climate change. In addition, they highlighted the research gap of previous studies to promote the multidisciplinary monitoring of groundwater and dependent ecosystems to enhance understanding. Kuss and Gurdak [30] analyzed the variability in the groundwater level in a principal aquifer system of the United States. Singular spectrum analysis, wavelet coherence analysis, and lag correlation approaches were used to understand the impacts of climate on groundwater. Multi-decadal (more than 50 years) hydro climate data were used for the study. However, most of the climatic studies have been performed by considering historical evidence (such as Kuss and Gurdak [30]; Meixner et al. [31]; Moeck et al. [32]) to quantify groundwater resources, but it is not always possible to obtain long-term historical data. Conversely, these data sets are very limited or highly uncertain in many countries. Chang et al. [33] studied the impacts of climate change and urbanization using a combination of numerical models such as 
MODFLOW, SWAT, and SEAWAT. However, limited field data were used for the study.

Meixner et al. [31] reviewed many recent articles related to the impacts of climate change on groundwater at global to local scales. In addition, other studies have also focused on forecasting long-term future impacts due to climate change on groundwater ([34][35][36] [37][38]) to model future groundwater vulnerability using DRASTIC [39]; moreover, saltwater intrusion due to changes in recharge and rainfall patterns in a coastal aquifer has also been analyzed [40]. The aforementioned studies have utilized combinations of several approaches and different numerical models such as global climate model (GCM) and regional climate model (RCM) methods. Smerdon [25] suggested the inclusion of groundwater recharge mechanisms in GCMs.

Several numerical models (land surface based) have been used to study the impacts of climate change on groundwater. These studies have measured variations in recharge rates as a result of climatic variations in precipitation. However, Kløve et al. [27] reported that the uncertainty associated with climate modeling techniques such as numerical modeling is high. A major limitation of many of these studies is that they have primarily focused on modeling the temporal variations in the hydrologic processes and overlooked the spatial variations due to model and data limitations. The lack of continuous long-term spatiotemporal data may limit the accuracy and understanding of the estimated model, which is a common problem faced by hydrogeologists. Hence, this problem hinders the accurate estimation and analysis of groundwater data. The studies discussed above indicate that the changes in temperature and precipitation are mostly due to the changing climate. However, it is vital to observe that the conclusions drawn from these studies directly depend on the availability of hydrological data. Therefore, an expansion of the GWLMN is needed to collect long-term field data in relation to climate change [23].

Information to know the impact of climate change on $\mathrm{GW}$ availability also requires well-designed GWLMN. Climate change affects the more sensitive areas which have low storage coefficients or excessive base flows and long-term management in such areas would call for more appropriate and scientific information of GW fluctuations. Therefore, designing of a network becomes more important.

\subsection{Quantitative assessment of GWL in space and time}

Excessive pumping of groundwater for irrigation, domestic, and industrial use has a significant impact on the availability of groundwater. The consequence of excessive groundwater pumping is directly reflected in the groundwater levels. As stated by Margat and van der Gun [41], the total global groundwater withdrawal is $982 \mathrm{~km}^{3} / \mathrm{yr}$. If the demand for groundwater increases at such a rapid pace, then most of the aquifers in the world may get overexploited. In many nations, groundwater has been withdrawn excessively at higher rates (Table 2). The top ten groundwater exploiting nations with the highest groundwater withdrawals are illustrated in Table 2. In many parts of these countries, the irrigation sectors utilize more than $60 \%$ of the total groundwater withdrawal. In some parts of the countries, the groundwater abstraction in the irrigation sector ranges from $75-95 \%$ of the total groundwater use in the world. These scenarios have been observed in different countries such as Pakistan, India, Saudi Arabia, Syria, Iran, Bangladesh, Mexico, the United States, Italy, Turkey, China, Japan, Thailand, Russia, and Indonesia.

It is essential to observe and understand the groundwater levels prior to drilling any new wells. In addition, the groundwater level data collected from monitoring wells provide information about the status of the existing pumping wells. Hence, local water managers can obtain information and the status of the groundwater table. The spatiotemporal information collected from a GWLMN is vital for decision makers and water resource managers to avoid overexploitation situations. These data also provide useful information about groundwater recharge even at the local scale. In several regions, decreasing GWLs have large impacts on groundwater quality and quantity [24]. For instance, in coastal areas, when there are excess freshwater demands (due to over withdrawal), saltwater intrusion may occur, and aquifers may become contaminated. Therefore, quantitative spatial and temporal assessments of groundwater are important to facilitate better groundwater management practices.

The field data collected through GW observation wells is required to know the status of groundwater in a particular region and this basic input is obtained from the observation well networks. If the GWLMN is not properly designed indicating appropriate numbers and locations of observation wells, it would lead to unscientific monitoring of groundwater in the area then it would be very difficult to know the status of groundwater. Systematic and continuous monitoring is very useful for the management of the groundwater resources and the basic input required is groundwater level data, which correctly represents the actual GW situation in the area which may only be obtained from the network of observation wells. Denser the network more authentic will be the groundwater.

\subsection{Surface water and groundwater interaction}

Recent studies based on GW-SW interactions have been widely reported as these interactions adversely affect the groundwater quality/salt water intrusion [42] and [27], GWSW assessments [43], flood management research [44] [45] and [46], climate change [47], water scarcity [48], drought [49], wetlands [50], etc. A better understanding and estimation of GW-SW interactions at regional and local scales is significant for water resource managers and practitioners. For example, Wu et al. [51] summarized the surrogate-based approach that is used to optimize water resource management in large river basins by considering GW-SW interactions. The objective of the study was to optimize and estimate the GWSW utilization for irrigation purposes. A similar study was done on a local scale by Arumí et al. [51] in the Peumo Valley, Chile. The purpose of the study was to estimate the seepage from canals to groundwater and its impact on the irrigation system in the river basin. Most of the GW-SW interaction phenomena can be observed on the regional scale $\left(10^{3} \mathrm{~km}^{2}\right.$ to $10^{5} \mathrm{~km}^{2}$ ) [53]; thus, in the previous literature [54], more importance was given to the GW-SW interactions at the regional scale than at the local and large scales.

Studies that monitor GW-SW interactions are necessary to understand and quantify the resources for their optimal use. For example, Brownbill et al. [55] proposed a brief report on surface and groundwater interactions in alluvial aquifers in the Murray-Darling Basin, Australia. This study highlighted the key challenges in managing GW-SW interactions in alluvial aquifers. The focus was to identify long-term water resource management practices and design a monitoring program for GW-SW interactions. Vsevolozhsky and Zektser [56] emphasized the need to estimate the quantity of water recharge or discharge into the river/aquifer that was due to GW-SW interactions. They also suggested that in addition to the natural hydrogeological phenomena, anthropogenic 
activities are also essential to determine and establish the relationship between $\mathrm{GW}-\mathrm{SW}$ interactions.

In many parts of the world (including the fifteen highest GW abstraction countries), GWL data related to GW-SW interactions are missing or very limited. Brownbill et al. [55] suggested to develop monitoring infrastructure to better understand the connectivity and interaction between surface and groundwater. The quantity of available field data associated with GW-SW interactions is not adequate to create realistic models. Brunner et al. [56] also stressed on field data collection to observe the disconnection/connection between GW-SW. Hence, the emphasis has been placed on the design of coupled GW-SW monitoring networks to measure GWSW fluxes continuously.

It may not be an exaggeration to say that modern approach of GW management should essentially be based on the principle of 'Integrated GW and SW replenishment'. As the same watershed as an unit has to be utilized for harnessing the runoff which is required to surface as well as GW resources, SW and GW interface and its manifestations require scientifically designed GWLMN for integrated management of SW and GW resources. Areas showing little GW fluctuations and GW recharge, as it happens in complex metamorphic terrains, may be advocated to have more surface water development as compared to GW recharge. GWLMN have greater role to play here which helps in reaching to such critical inferences and resulting implementation decisions. Scientific information on GW availability and dynamism is must for effective GW -SW interface.

\subsection{Land subsidence and GWLMN}

The principal cause of land subsidence is excessive groundwater withdrawal [58] and [59]. Land subsidence generally occurs in regions with unconsolidated alluvium and coastal areas. Remotely sensed data are commonly used to record land subsidence [60]. Many attempts have been made to measure, monitor and map land subsidence. For example, Chang et al. [61] and Chu et al. [62] described a genetic algorithm-based approach to design a possible network and pumping well expansion schedule. The approach was intended to design an optimum pumping schedule to solve the land subsidence problem emerging from excessive pumping of groundwater. Kearns et al. [63] presented a case study of the Houston metropolitan region to understand land subsidence in association with GWL changes. This study utilized monitoring well data and global positioning system measurements to map and analyze the relationship between GWLs and land subsidence.

To study the relationship between GWL variations and land subsidence, several methods such as statistical methods [64] and [65], experimental methods [66], numerical methods [67], finite-layer methods [68], and genetic algorithms [62] were reported in the last decade. All of these methods are mostly based on data obtained from monitoring networks of observation wells, while land subsidence was generally mapped using interferometric synthetic aperture radar (InSAR) [59], [60], and [69].

Recently, a few studies were conducted to understand and analyze land subsidence in different parts of the world such as the USA ([102], [63], and [70]), China ([71], [72], [65]), Italy [73], India [74], and Vietnam [59]. In general, it was found that most of the coastal areas with thick alluvium aquifers and high groundwater withdrawals are more prone to land subsidence ([3] and Table 3). Most of the studies that appeared in recent decades commonly utilized observation wells and remotely sensed data to understand and map land subsidence. However, fewer studies were reported in the past that directly dealt with the design of a GWLMN in relation to land subsidence. Hence, long-term and systematic designs of GWL and other ground-based measurements are required to manage groundwater resources and control land subsidence.

Table 3 .Groundwater monitoring in relation to land subsidence [3]

\begin{tabular}{c|l|l}
$\begin{array}{c}\text { S. } \\
\text { No. }\end{array}$ & Continent & Countries \\
\hline 1. & Asia & $\begin{array}{l}\text { China, India, Korea, Indonesia, } \\
\text { Japan, Myanmar, Thailand }\end{array}$ \\
& & South Africa, Djibouti \\
2. & Africa & USA \\
3. & $\begin{array}{l}\text { North } \\
4 .\end{array}$ & $\begin{array}{l}\text { America } \\
\text { South }\end{array}$ \\
5. & $\begin{array}{l}\text { America } \\
\text { Europe }\end{array}$ & Argentina, Brazil, Uruguay \\
\hline
\end{tabular}

Areas with excessive withdrawals may lead to land subsidence, especially in the soft rock areas like alluviums or soft shale or sandstones or even in Karst regions with limestone or even in the coastal areas. Here, the design of GWLMN would required in depth information on the various parameters affecting the GW storage and movement including the aquifer characteristics. The present study has included certain such parameters. Frequency of monitoring may have a crucial role along with appropriate locations in such cases where land subsidence may be anticipated.

\section{Groundwater level monitoring approaches}

\subsection{Geostatistical methods}

Geostatistical methods (synonymous to kriging interpolations) area group of statistical techniques used to evaluate and predict variations in space and time [75]. The mathematical concept was first introduced by D.K. Krige in 1951 [76]. Initially, this method was developed to investigate subsurface minerals and solve mining-related problems. Further, Matheron [76] modified the method developed by D.K. Krige and introduced the general form of kriging. Geostatistical methods based on variance, semivariogram evaluations, and regionalized variable theories are used to compute accurate spatial distributions, determine the accuracies of those distributions and obtain optimal sampling locations for monitoring groundwater. Geostatistical (kriging) methods have been applied in various disciplines such as soil science, surface and subsurface hydrology, meteorology, atmospheric science, and agriculture. Winter [77] suggested the importance of statistics and sampling theory to develop and design guidelines for monitoring groundwater. Heath [14] suggested that a specific objective-based groundwater network should be designed. For example, the network should evaluate groundwater recharge and discharge using a monitoring network of observation wells.

Several forms of kriging were also introduced, such as universal kriging, cokriging and disjunctive kriging. Geostatistical (kriging) techniques have been used in network design since the 1980s. However, the networks were previously designed based on scientific information and experience of the water resource managers [9].

Sections (4.1.1-4.4) discuss different approaches along with their basic principles, assumptions and underlying 
strength and weakness (Table 4 and Table 5) for designing GWLMN. Hughes and Lettenmaier [15] suggested the design of an observation well network based on data requirements and implications of the kriging method. As per the peerreviewed journals, Sophocleous et al. [16] first applied the geostatistical method to redesign a groundwater network. This technique was applied to evaluate and redesign the GWLMN based on error variance criteria. Olea [17] suggested that a combination of universal kriging and gridbased approaches could be used to reduce sampling efforts. Szidarovszky [18] followed a similar method to design an observation network. This method was applied to select drilling strategies in hydrology and mining applications. Bogardi and Bardossy [19] proposed a general methodology to design an observation well network using a combination of geostatistical and multi-criteria decision making (MCDM) techniques. The network was designed to incorporate measurements and designs of different environmental variables. Similar studies, for instance studies by Osburn [78], [79], [80], [81], [82], and [83] have been carried out to design GWLMN using geostatistical methods (Table 4).

Table 4. Historical details of approaches used to design GWLMNs (in sequential order)

\begin{tabular}{|c|c|c|c|c|c|}
\hline S.N. & Source & $\begin{array}{c}\text { Input } \\
\text { data/parameters }\end{array}$ & $\begin{array}{c}\text { Location details/ Study } \\
\text { area }\left(\mathrm{Km}^{2}\right)\end{array}$ & Methods & Key results \\
\hline 1. & [16] & GWL & $\begin{array}{l}\text { - Kansas, USA } \\
\text { - Area }=9000 \mathrm{~km}^{2}\end{array}$ & $\begin{array}{l}\text { Geostatistical } \\
\text { method }\end{array}$ & $\begin{array}{l}\text { - Existing network: } 327 \text { OW } \\
\text { - Optimized network: } 241 \\
\text { OW } \\
\text { - One well per } 6.4 \mathrm{~km} \times 6.4 \\
\mathrm{~km}\end{array}$ \\
\hline 2. & [18] & $\begin{array}{l}\text { GWL / drill hole } \\
\text { data }\end{array}$ & - USA & $\begin{array}{l}\text { Geostatistical } \\
\text { method }\end{array}$ & $\begin{array}{l}\text { - Existing network: } 59 \text { OW } \\
\text { - Optimized network: } 69 \text { OW }\end{array}$ \\
\hline 3. & [17] & GWL & $\begin{array}{l}\text { - Kansas, USA. } \\
\text { Area=2071 km² }\end{array}$ & $\begin{array}{l}\text { Geostatistical } \\
\text { method }\end{array}$ & $\begin{array}{l}\text { - Existing network: } 244 \mathrm{OW} \\
\text { - Optimized network: } 47 \mathrm{OW}\end{array}$ \\
\hline 4. & [19] & $\begin{array}{l}\text { GWL, aquifer } \\
\text { thickness, and } \\
\text { porosity }\end{array}$ & $\begin{array}{l}\text { - Hungary. } \\
\text { - Area= Unknown }\end{array}$ & $\begin{array}{l}\text { Geostatistical } \\
\text { method and } \\
\text { MCDM }\end{array}$ & $\begin{array}{l}\text { - Existing network: } 7 \text { OW } \\
\text { - Optimized network: } 6 \mathrm{OW}\end{array}$ \\
\hline 5. & {$[115]$} & GWL & $\begin{array}{l}\text { - Erbil hydrogeological } \\
\text { basin, Iraq. } \\
\text { - Area: NA }\end{array}$ & $\begin{array}{l}\text { Statistical analyses } \\
\text { (Correlation) }\end{array}$ & $\begin{array}{l}\text { - Existing network: } 68 \text { OW } \\
\text { - Optimized network: } 15 \text { OW }\end{array}$ \\
\hline 6. & {$[120]$} & GWL & $\begin{array}{l}\text { - Leibnitzer-Feld, Austria. } \\
\text { - Area }=100 \mathrm{~km}^{2}\end{array}$ & $\begin{array}{l}\text { PCA, RV } \\
\text { coefficient, } \\
\text { Geostatistical }\end{array}$ & $\begin{array}{l}\text { - Existing network: } 118 \mathrm{OW} \\
\text { - Optimized/suggested } \\
\text { network: } 60 \mathrm{OW}\end{array}$ \\
\hline 7. & {$[121]$} & GWL & $\begin{array}{l}\text { Yolo County Basin, } \\
\text { Calif, USA. } \\
\text { - Area }=400 \mathrm{~km}^{2}\end{array}$ & $\begin{array}{l}\text { Geostatistical } \\
\text { method: Kriging } \\
\text { and Cokriging, } \\
\text { Branch and Bound } \\
\text { algorithm }\end{array}$ & $\begin{array}{l}\text { - Existing network: } 14 \mathrm{OW} \\
\text { - Optimized/suggested } \\
\text { network: } 10 \mathrm{OW}\end{array}$ \\
\hline 8. & {$[78]$} & GWL & $\begin{array}{l}\text { - Upper Floridan aquifer, } \\
\text { USA. } \\
\text { - Area }=68116 \mathrm{~km}^{2}\end{array}$ & $\begin{array}{c}\text { Geostatistical } \\
\text { method: Kriging }\end{array}$ & $\begin{array}{l}\text { - Existing network: } 943 \text { OW } \\
\text { - Optimized network: } 442 \\
\text { OW } \\
\text { - One well in each hexagonal } \\
\text { grid (diameters of } 13.72 \\
\text { km) }\end{array}$ \\
\hline 9. & [79] & GWL & $\begin{array}{l}\text { - Kongal basin, India. } \\
\text { - Area }=180 \mathrm{~km}^{2}\end{array}$ & $\begin{array}{l}\text { Geostatistical } \\
\text { method: Kriging }\end{array}$ & $\begin{array}{l}\text { - Existing network: } 32 \mathrm{OW} \\
\text { - Optimized network: } 24 \mathrm{OW}\end{array}$ \\
\hline 10. & {$[116]$} & GWL & $\begin{array}{l}\text { - Bangkok, Thailand. } \\
\text { - Area }=5600 \mathrm{~km} 2\end{array}$ & PCA & $\begin{array}{l}\text { - Existing network: } 258 \text { OW } \\
\text { - Optimized network: } 172 \\
\text { OW }\end{array}$ \\
\hline 11. & [117] & GWL & $\begin{array}{l}\text { - Whatcom County, } \\
\text { - USA. Area }=629 \mathrm{~km}^{2}\end{array}$ & $\begin{array}{l}\text { Support vector } \\
\text { machines }\end{array}$ & $\begin{array}{l}\text { - Existing network: } 280 \text { OW } \\
\text { - Optimized network: } 250 \\
\text { OW }\end{array}$ \\
\hline 12. & [118] & GWL & - Hypothetical area & $\begin{array}{l}\text { Simulated } \\
\text { annealing }\end{array}$ & $\begin{array}{l}\text { - Existing network: } 38 \mathrm{OW} \\
\text { - Optimized network: } 23 \mathrm{OW}\end{array}$ \\
\hline 13. & [84] & GWL & $\begin{array}{l}\text { - Daqing region, China. } \\
\text { Area }=7,000 \mathrm{~km}^{2}\end{array}$ & Kalman filtering & $\begin{array}{l}\text { - Existing network: } 38 \mathrm{OW} \\
\text { - Optimized network: } 50 \mathrm{OW} \\
\text { - One well per } 80 \mathrm{~km}^{2}\end{array}$ \\
\hline 14. & {$[80]$} & GWL & $\begin{array}{l}\text { - Upper Bari Doab Canal } \\
\text { Tract, India. } \\
\text { - Area }=8590 \mathrm{~km}^{2}\end{array}$ & $\begin{array}{l}\text { Geostatistical } \\
\text { method: Universal } \\
\text { Kriging }\end{array}$ & $\begin{array}{l}\text { - Existing network: } 174 \text { OW } \\
\text { - Optimized network: } 146 \\
\text { OW } \\
\text { - One well per } 5 \mathrm{~km} \text { by } 5 \mathrm{~km} \\
\text { grid }\end{array}$ \\
\hline
\end{tabular}




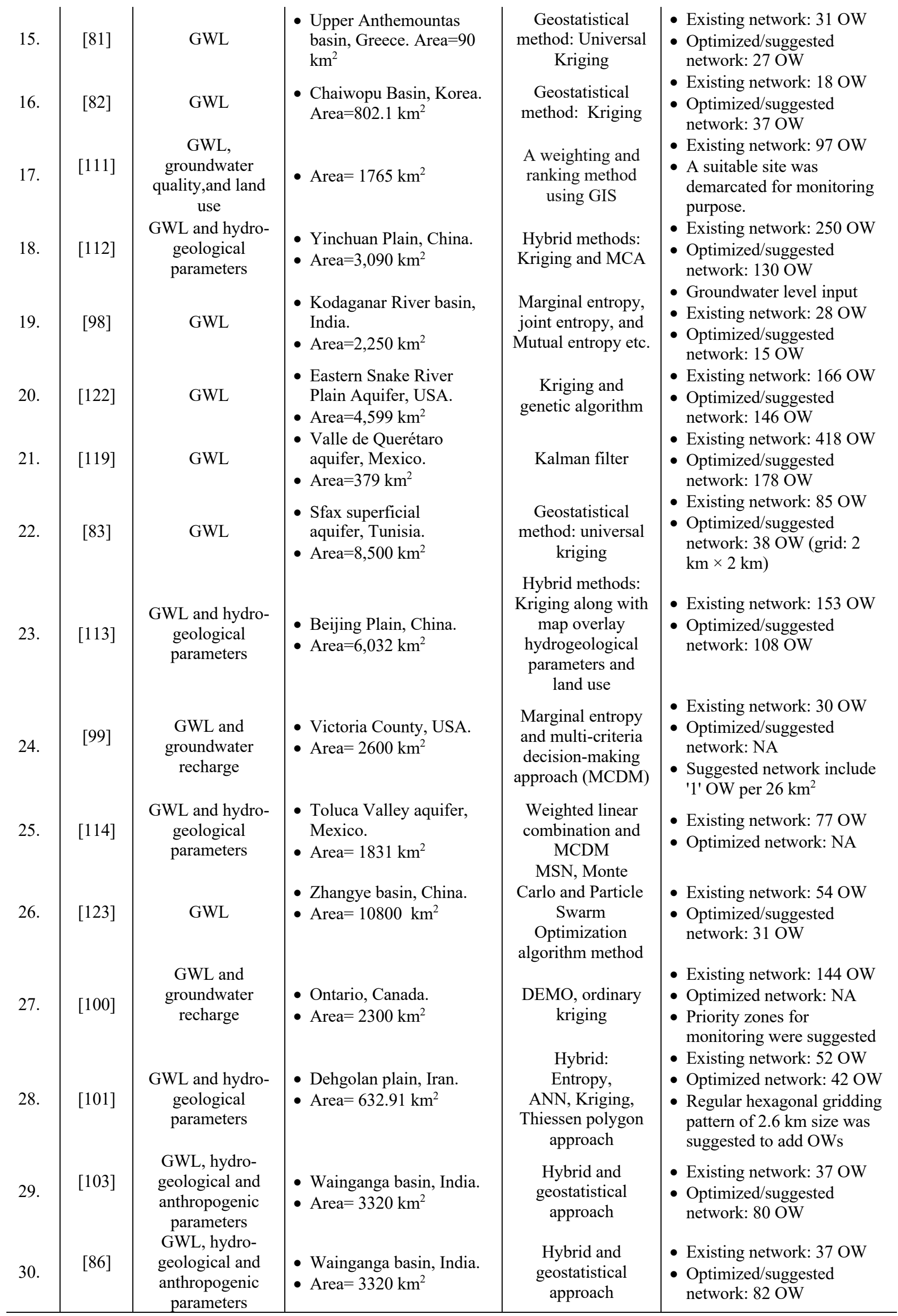


PCA: Principal component analysis; GWL: Groundwater level; GWLMN: Groundwater level monitoring network; MCDM: Multi-criteria decisionmaking approach; MSN: Mean of surface with non-homogeneity; DEMO: Dual Entropy-Multi objective Optimization model; ANN: Artificial, Neural Network

Table 5. The strengths and weaknesses of different approaches used to design GWLMNs

\begin{tabular}{llll}
\hline S.N. & Methods & Strength (\#) and Weakness (») & Authors \\
\hline 1 & $\begin{array}{l}\text { Geostatistical } \\
\text { method: kriging }\end{array}$ & $\begin{array}{l}\text { \# The first systematic study was conducted to design the GWLMN using the } \\
\text { geostatistical method. }\end{array}$
\end{tabular}

\# The error variance criterion was used as the basis for selecting the optimal set of solution.

\# The method used in the study was to achieve the satisfactory arrangement of the existing network using universal kriging.

\# The major advantage of this approach is that it was reliable and very useful for upgrading the existing network.

\# Emphasis was given to create an adequate monitoring network for quantitative assessment of groundwater resources

" The research had tended to focus on proposing a new and reliable method to optimize the network. The proposed method used only groundwater level data as input (single variable) and it cannot be applied to solve multi-objective problems.

\# This study illustrates a general methodology to improve the drilling strategies in hydrological and mining-related applications.

\# This study provides the importance of mathematical models and algorithms for regionalized variables.

" In this approach, the geostatistical method was described broadly to design groundwater level monitoring network (GWLMN).

\# The sampling pattern and density of the network at the time designing the GWLMN were given more importance.

\# Average standard error and maximum standard error criteria were applied to select the optimum location.

" A Geostatistical method is a group of statistical technique which considers only a mathematical relationship for design, but scientific variables such as hydrogeology, precipitation, the seasonal change was neglected.

\# The study area was divided into different grid pattern such as uniform hexagonal spacing, uniform square spacing, regular hexagonal, random and clustered gridding pattern. The variance based criteria were used to select the suitable grid.

" The study was undertaken to apply geostatistical method as a case study and emphasis was given to spatial location observation wells.

" A major drawback is that the author has taken only one-year GWL data. [79]

\# Study area was divided into a systematic network of the grids and sensitivity analysis [80] was performed to select the optimum network.

"Single variable input (GWLs) has been used to design the network.

\# The method is essentially the same as that used by Kumar et al. (2005) with some modifications. For example, Spatio-temporal variance-based approach was applied to optimize GWLMN.

\# Geostatistical methods were used to solve the monitoring networks. Additionally, the main advantage is that different semivariogram models such as gaussian, exponential, and spherical were also used for accuracy assessment.

"The main drawback of this approach is that it does not consider aquifer properties and other hydrogeological parameters.

\# The main advantage of this method was that iterative procedure was followed to select the set of OWs which yielded a minimum error.

" The period of analysis is less (one-year data) and more emphasis was given to the spatial location of OWs.

\begin{tabular}{llll}
\hline 2 & $\begin{array}{l}\text { Statistical } \\
\text { analyses } \\
\text { (Correlation) }\end{array}$ & $\begin{array}{l}\text { \# Groundwater level fluctuation was considered as the important factor to optimize the } \\
\text { existing GWLMN. } \\
\text { " This study had described the importance of hydrogeological conditions responsible } \\
\text { for groundwater level rise/fall but this method fails to quantify the network based on } \\
\text { the hydrogeological conditions. }\end{array}$ \\
\hline 3 & $\begin{array}{l}\text { PCA, RV } \\
\text { coefficient, } \\
\text { Geostatistical }\end{array}$ & $\begin{array}{l}\text { \# This study had focused on the limitations of variogram model during the design of } \\
\text { monitoring network. } \\
\text { \# In order to overcome the previous limitations, three approaches such as particle } \\
\text { component analysis, arithmetic mean and general relative variogram were applied. It } \\
\text { was found that the general relative variogram yielded better results. } \\
\text { " Seasonal variations were not considered to optimize the network. }\end{array}$ \\
\hline 4 & $\begin{array}{l}\text { Geostatistical } \\
\text { method: Kriging }\end{array}$ & $\begin{array}{l}\text { \# In addition to geostatistical approach, branch and bound algorithm was introduced } \\
\text { to select the optimal monitoring sites. }\end{array}$ \\
\hline
\end{tabular}

\section{-}


and Cokriging, \# The major advantage of this method is that it utilizes multivariate approach.

Branch and \# Aquifer transmissivity and specific capacity were employed as input during the Bound design of the network.

algorithm ॥ The proposed method had utilized only static variables (Transmissivity and Specific) for designing the monitoring network.

5 Principal \# PCA was applied innovatively to evaluate and optimize the GWLMNs. The main component advantage of this method was that the relative importance of individual wells can be analysis (PCA) estimated.

» PCA method cannot be applied directly to compute the variables in space and time as compared to the geostatistical method.

\begin{tabular}{|c|c|c|c|}
\hline 6 & $\begin{array}{l}\text { Support vector } \\
\text { machines } \\
(\mathrm{SVM})\end{array}$ & $\begin{array}{l}\text { \# The major advantage of SVM is that it can directly estimate the optimum sets of } \\
\text { wells. } \\
\text { \# The SVM method can predict the GWLs at the unobserved location using a different } \\
\text { set of functions. } \\
\text { " In this method, only GWL data as input has been utilized. It does not analyze the } \\
\text { frequency and seasonal variations. }\end{array}$ & [117] \\
\hline 7 & $\begin{array}{l}\text { Simulated } \\
\text { annealing (SA) }\end{array}$ & $\begin{array}{l}\text { \# This method analyses the cost of groundwater explorations and redundancy in space } \\
\text { and time. } \\
\text { »Hypothetical monitoring network was used for analysis. In this method, variables } \\
\text { such as GWLs and type of grid were assumed as homogeneous and continuous. } \\
\text { Conversely, these data sets are discontinuous (missing) and irregular. }\end{array}$ & {$[118]$} \\
\hline 8 & $\begin{array}{l}\text { Finite element } \\
\text { and Kalman } \\
\text { filtering }\end{array}$ & $\begin{array}{l}\text { \# The main advantage of this method is that it gives the combinations of network } \\
\text { density and frequency of groundwater monitoring. } \\
\text { »Hydrogeological and anthropogenic variables were not considered at the time of } \\
\text { designing the network. }\end{array}$ & [84] \\
\hline 9 & $\begin{array}{l}\text { Marginal } \\
\text { entropy, joint } \\
\text { entropy, and } \\
\text { Mutual entropy } \\
\text { etc. }\end{array}$ & $\begin{array}{l}\text { \# The main advantage of this method is that it considers spatial and temporal variations } \\
\text { to optimize the network. In addition, it also estimates the relative importance of one } \\
\text { observation wells with other and computes the optimum distance between the two } \\
\text { OWs. } \\
\text { " In spite of the novelty in this approach, environmental and hydrogeological variables } \\
\text { were not considered for the analysis. }\end{array}$ & [98] \\
\hline 10 & $\begin{array}{l}\text { Kriging and } \\
\text { genetic } \\
\text { algorithm }\end{array}$ & $\begin{array}{l}\text { \# The main advantage is that genetic algorithm approach and kriging method were } \\
\text { combined to select the optimum number of observation wells in the existing } \\
\text { monitoring network. } \\
\text { \# Standard error and RMSE indices were used to estimates the inconsistencies for a set } \\
\text { of OWs. } \\
\text { » In this approach, only GWL data (Single variable) was used as input. }\end{array}$ & [122] \\
\hline 11 & $\begin{array}{l}\text { Kalman filter } \\
\text { and sequence- } \\
\text { based } \\
\text { optimization }\end{array}$ & $\begin{array}{l}\text { \# This method can be used effectively to select the optimal location of wells in space } \\
\text { and time. } \\
\text { »Hydrogeological characteristics of the aquifer and other additional variables were } \\
\text { not considered in this approach. }\end{array}$ & [119] \\
\hline 12 & $\begin{array}{l}\text { Marginal } \\
\text { entropy and } \\
\text { multi-criteria } \\
\text { decision- } \\
\text { making } \\
\text { approach } \\
\text { (MCDM) }\end{array}$ & $\begin{array}{l}\text { \# Marginal entropy and MCDM approach were combined to prioritize the areas for } \\
\text { monitoring groundwater. The monitoring priority index (MPI) was proposed to select } \\
\text { the appropriate zone for monitoring. } \\
\text { " This method only delineates the priority zones for monitoring the network but was } \\
\text { unable to justify the number of wells to be included in the network. }\end{array}$ & [99] \\
\hline 13 & $\begin{array}{l}\text { MSN, Monte } \\
\text { Carlo and } \\
\text { Particle Swarm } \\
\text { Optimization } \\
\text { algorithm } \\
\text { method }\end{array}$ & $\begin{array}{l}\text { \# The main advantage this approach is that it can be applied to non-homogenous } \\
\text { conditions (i.e. seasonal and hydrogeological variations). } \\
\text { " The proposed method cannot be applied to solve multi-objective optimization } \\
\text { problems. Also, this method is not suitable in absence of historical GWL data. }\end{array}$ & [123] \\
\hline 14 & $\begin{array}{l}\text { DEMO and } \\
\text { Ordinary } \\
\text { Kriging }\end{array}$ & $\begin{array}{l}\text { \# The main advantage of this study is that groundwater recharge was considered as the } \\
\text { important criteria for delineating the priority zones for monitoring the network. } \\
\text { " The methodology presented in this study is limited to identifying monitoring zones } \\
\text { but the approach may be further used to optimize the number of observation wells } \\
\text { within the priority zones. }\end{array}$ & {$[100]$} \\
\hline 15 & $\begin{array}{l}\text { Hybrid:Entropy, } \\
\text { ANN, Kriging, } \\
\text { Thiessen } \\
\text { polygon } \\
\text { approach }\end{array}$ & $\begin{array}{l}\text { \# A new data fusion based methodology was introduced to design GWLMN. ANN, } \\
\text { entropy, and geostatistical approaches were used in GIS environment. A systematic } \\
\text { methodology has been proposed to design the network by spatiotemporal variations. }\end{array}$ & {$[101]$} \\
\hline
\end{tabular}




\begin{tabular}{|c|c|c|}
\hline \multirow[t]{7}{*}{16} & \multirow[t]{7}{*}{$\begin{array}{l}\text { Hybrid } \\
\text { methods: } \\
\text { geostatistical } \\
\text { approach a } \\
\text { MCDM }\end{array}$} & $\begin{array}{l}\text { \# Multi-variables such as GWLs, aquifer thickness, and porosity were employed to } \\
\text { design the network. } \\
\text { " Geostatistical method was based on the two basic assumptions: prior variogram } \\
\text { information is known and variogram is assumed to be time-dependent but variables } \\
\text { used for designing the network are limited and it changes with a change in space and } \\
\text { time. }\end{array}$ \\
\hline & & $\begin{array}{l}\text { \# This approach was applied to identify the suitable zones for regional groundwater } \\
\text { quality and quantity network. } \\
\text { \# Land use/land cover (for groundwater quality) and lineament density were employed } \\
\text { as the variable parameters. } \\
\text { " This approach provides probable spatial locations for monitoring the network but it } \\
\text { unable to estimate the optimum number of OWs. }\end{array}$ \\
\hline & & $\begin{array}{l}\text { \# The main advantage of this method was that it demonstrates the combination of } \\
\text { geostatistical method and GIS tool for designing the GWLMN. } \\
\text { » This method fails to analyze the seasonal and anthropogenic variables, which play a } \\
\text { significant role in groundwater occurrence and movement. }\end{array}$ \\
\hline & & $\begin{array}{l}\text { \# A new approach was introduced to design GWLMN. Hydrological variables were } \\
\text { used as additional input to design GWLMN. } \\
\text { " This study utilizes several hydrogeological and anthropogenic parameters but it } \\
\text { unable to quantify the relationship of these parameters with the change in GWLs. } \\
\text { » Seasonal variations and frequency of monitoring were neglected. }\end{array}$ \\
\hline & & $\begin{array}{l}\text { \# This study introduces the MCDM approach integrated in GIS environment to [114] } \\
\text { delineate the priority zones for GWLMN. } \\
\text { » The weights assigned to variable parameters were based on the qualitative behavior } \\
\text { rather than the quantitative. }\end{array}$ \\
\hline & & $\begin{array}{l}\text { \# The main advantage of this method is that it proposed a new methodology to design } \\
\text { groundwater level monitoring network in the complex aquifer system. } \\
\text { " Frequency of monitoring wells and identification of priority zones were not } \\
\text { considered in the given methodology. }\end{array}$ \\
\hline & & $\begin{array}{l}\text { \# The main advantage of this method was that it identifies the priority locations and } \\
\text { optimized the number of wells within the identified locations. } \\
\text { " Surface and groundwater variables responsible for optimization of GWLMN were } \\
\text { qualitatively identified and analyzed, but this approach can be improved by estimating } \\
\text { variables quantitatively with respect to change in groundwater levels. }\end{array}$ \\
\hline
\end{tabular}

SE (standard error), RMSE (root mean square standard error); mean of surface with non-homogeneity (MSN) method, DEMO: Dual Entropy-

Multiobjective Optimization mode

For example, a geostatistical tool (kriging) application for identifying optimum sites for monitoring groundwater levels was proposed by Prakash and Singh [79] using groundwater level data from 32 observation wells in the upper Kongal basin, Nalgonda District, Andhra Pradesh, India. A krigingbased genetic algorithm was demonstrated to optimize and design the long-term groundwater-monitoring network using GWL data [84]. Ahmadi and Sedghamiz [5] analyzed the spatial and temporal changes in groundwater level variations in 39 piezometric wells over 12 years period using a geostatistical approach.

Geostatistical methods are very effective and useful for creating semivariograms and error maps. Semivariograms and error maps measure the precision and bias of monitoring samples. Hence, based on the error criteria, monitoring networks have been redesigned or optimized [85]. Most of the studies discussed above were based on univariate analyses. These studies utilized single variables such as 'groundwater level data' as the inputs. Conversely, groundwater is a complex system that is governed by several anthropogenic and natural factors. However, with the advancement of geoinformatic technology, many researchers have adopted combinations of (MCDM) and geostatistical methods to evaluate and design GWLMN [86].

\subsection{Entropy}

Shannon introduced the theory of entropy or information theory, which estimates the uncertainty in random variables [87] and [88]. An increase in entropy values is linked with a loss of information and decrease in entropy values shows a gain in information. The concept of entropy has been widely used in many areas of water resource and environmental science, such as rainfall-runoff simulations, soil moisture research, and groundwater quantity investigation ([10], [89], and [90]). For example, stream flow [91], water quality [92] surface water level [93], groundwater quality ([94] and [95]), and precipitation networks ([96] and [97]) have been investigated by several researchers. Marginal entropy (ME), joint entropy (JE), mutual or transinformation entropy (TE), and conditional entropy (CE) have been commonly used in water resources and other allied disciplines.

Mondal and Singh [98] were probably the first researchers to implement the concept of entropy theory in the design of a GWLMN. The study was conducted in the Kodanagar basin, India. The existing GWLMN was assessed and redesigned using ME, TE, JE, and CE. Subsequently, several other researchers ([99], [100], [101], and [102]) have modified and redesigned GWLMNs by combining entropy with other approaches. For instance, Uddameri and Andruss [99] employed geographic information system (GIS)-based MCDM and entropy theory to design a GWLMN at a regional scale. Leach et al. [100] applied the dual entropymultiobjective optimization (DEMO) method in Ontario, Canada. In this study, annual groundwater recharge criteria along with entropy theory concepts were considered to design a GWLMN. Hosseini and Kerachian [101] also employed entropy theory with the concepts of artificial neural network (ANN), kriging, and Thiessen polygon approaches to 
redesign a GWLMN in Dehgolan, Iran. Singh and Katpatal [103] emphasized the inclusion of complex variables such as: heterogeneous aquifer properties, surface water, and natural and anthropogenic change to assess and design a GWLMN using entropy theory.

Despite all the advantages and wide ranges of applications, entropy theory cannot be directly applied in the absence of field data. For instance, a monitoring network cannot be evaluated and designed if historical data are absent. Entropy theory is able to evaluate the uncertainty of random variables in space and time, but the outcome is discontinuous in the spatial domain. To overcome these limitations, inclusion of the geostatistical methods along with entropy theory can facilitate the long-term and continuous assessments of complex hydrological parameters in space and time.

\subsection{Multi-criteria/hybrid analysis}

McHarg [104] introduced the concept of map overlay to investigate the ecology of a landscape. With the advancement of geo-informatic approaches and especially map overlay techniques, many complex and dynamic hydrogeological variables have been investigated and studied effectively. Over the past several decades, several applications of map overlay analyses in the field of environment and water resources have been reported, such as estimations of sediment yield [105] and flood-affected zones [106]; runoff estimations using soil conservation service (SCS) curve numbers (CNs) [107]; groundwater vulnerability zones [108], and groundwater potential zones [109]; and land-use suitability analyses [109]. Map overlay techniques are able to analyze and visualize complex hydrological phenomena more easily and precisely. With the evolution and advancements of overlay analysis, various scientific parameters associated with the occurrence and movement of groundwater can be effectively analyzed and investigated. Hence, the understanding and mapping the groundwater in space and time has become simpler.

In recent years, considerable interest was shown by Bogardi and Bardossy [19], [111], [112], [113], [99], [114], [100] and [101] to examine and design GWLMNs using hybrid approaches (combination of multicriteria and statistical analyses). Bogardi and Bardossy [19] suggested a generalized framework to include MCDM with geostatistical methods to design a GWLMN. The authors recommended adding aquifer thickness and porosity to the network designs. Kim [111] used weight and ranking methods to design a groundwater quality and quantity network. Further, Chao et al. [112], Zhou et al. [113], and Esquivel et al. [114] applied kriging and MCDM methods with the inclusion of hydrogeological parameters to design monitoring networks (Table 4). Uddameri and Andruss [99] applied ME and MCDM methods, while Leach et al. [100] applied dual entropy-multiobjective optimization (DEMO) and groundwater recharge criteria to evaluate and design a network. Hosseini and Kerachian [101] proposed a new method to design a GWLMN, which includes entropy, ANN, kriging, Thiessen polygon and overlay analyses. Singh and Katpatal [102] proposed a method to design a GWLMN in the complex aquifer system of the Wainganga basin, India. These authors used AHP, fuzzy, and weighted overlay techniques along with several hydrogeological and anthropogenic parameters.

The inclusion of several parameters and different robust techniques has proven to be very effective and efficient to design a GWLMN. The methods discussed are efficient and well-organized, but some of these methods are time- consuming and require extensive field data. Despite the advantages of the aforementioned literature, these methods are site-specific and have not yet been applied to very large areas (globally).

The main advantage of using hybrid method is that it has the potential of demarcating the priority zones for monitoring in cases where field data is unavailable. For instance, geostatistical methods and other design techniques need the input variables derived from field data and these methods are not suitable in absence of field data. Conversely, even in absence of field data, hybrid methods in GIS environment can be used to delineate priority zones within the monitoring network. For example, different thematic map layers containing specific thematic information can be superimposed using MCA in GIS environment to select the priority zones for monitoring. Further, if these methods are used with available field data then the accuracy will be more. Optimized network obtained using hybrid methods can be effectively applied to upgrade the existing network of observation wells.

\subsection{Other design approaches}

Geostatistical, entropy, and multicriteria analysis approaches have frequently been used to design monitoring networks. These methods have been applied separately or in combination with each other. However, other monitoring approaches used separately or in combination with geostatistical approaches. These approaches have also been applied to design existing groundwater level monitoring networks. For example, statistical correlation analyses [115], principal component analyses (PCAs) [116], support vector machines [117], simulated annealing [118], and Kalman filtering [84] have been applied separately.

Jawad and Karam [115] applied statistical crosscorrelations methods, which assume GWLs data at each OWs location, as random variables. The data from the each OW is represented in a matrix form of $\mathrm{n} x \mathrm{p}$ dimension. The general form of the equation of statistical cross-correlation is represented as:

$$
\operatorname{RV}(X, Y)=\frac{\sum_{j=1}^{p} r_{i j}^{2}}{\left(\sum_{j=1}^{p} \sum_{j=1}^{p} r_{i j}^{2}\right)^{1 / 2}}
$$

where $\mathrm{n}$ is monthly GWL data, $\mathrm{p}$ is number of OWs, RV is the correlation between random variables $\mathrm{X}$ and $\mathrm{Y}, r_{i j}$ is cross-correlation coefficient between the $i^{\text {th }}$ and $j^{\text {th }}$ variables.

Similarly, Gangopadhyay et al. [116] demonstrated the PCA method to optimize the existing network of observation wells. PCA is a statistical technique that utilizes the set of correlated variables (GWLs) to evaluate the heterogeneity or homogeneity present in the data sets. This correlated variable is further used as the decision-making tool to select the optimum location of observation wells. It was assumed that correlations indicate the complexity of aquifer hydrogeology. Information present in the different set of observations wells were compared one at a time and number of the independent set of observation wells was selected as the priority wells for optimizations.

Further, Asefa et al. [117] used support vector machine (SVM) method to design GWLMN and concluded that SVM 
method was efficient to analyze spatial redundancy present in the data sets. SVM method is based on the statistical learning theory. The SVM predicts the values of random variable ' $Z$ ' at unobserved location $\mathrm{x}_{0}$ and the equation is given by:

$$
\hat{Z}(x)=\left(w_{s v}, x_{0}\right)+b
$$

where $w_{s v}$ is the support vector weight, and $\mathrm{b}$ is bias.

Júnez-Ferreira and Herrera [118] presented a geostatistical method for optimally designing a spatiotemporal hydraulic head-monitoring network in the Valle de Queretaro aquifer. The Kalman filter is a statistical technique that uses a set of known variable (i.e. a set of equations) to estimate unknown variables. The general form of Kalman filter can be expressed as:

$z_{j}=H_{j} h+v_{j}$

where, $\left(z_{\mathrm{j}}, \mathrm{j}=1,2,3,4 \ldots \ldots\right)$ is the estimated variable in space (h) and time; sampling matrix $H_{j}$ is of order $1 \times N, v_{j}$ is the measured error sequence of $\mathrm{j}^{\text {th }}$ samples. The spatiotemporal monitoring points were selected using a Kalman filter combined with a sequential optimization method. JúnezFerreira and Herrera [119] have stated that estimate-error covariance matrix can be estimated by geostatistical analysis. Further, it minimizes the error variance by utilizing all sets of monitoring locations in space and time and finally, spatiotemporal filtering optimization and successiveinclusion methods were applied to design the monitoring network.

These methods for the design of a GWLMN were proved to be systematic and well-organized; however, limited input parameters were used to design the networks. Other optimization approaches have also been used in combination with geostatistical methods. For example, Fuchs et al. [120] applied a combination of PCA and RV coefficients, BenJemaa et al. [121] used kriging, cokriging and a branch and bound algorithm, Fisher [122] used kriging with a genetic algorithm, and Ran et al. [123] used mean of the surface with non-homogeneity (MSN) in combination with Monte Carlo and particle swarm optimization (MC-PSO) algorithm methods (Table 4).

Methods such as genetic algorithms, MC-PSO, and simulated annealing have been widely applied in various disciplines to solve optimization problems. These methods have been applied less often to design GWLMNs. However, appropriate use of these methods with the inclusion of more variables such as hydrogeologic properties, groundwater fluxes (recharge, storage, discharge), and anthropogenic factors in designing the networks can yield better results.

The different design approaches for designing the GWLMN as discussed and suggested may be applied in a specific situation. For example, the geostatistical approach is commonly used approach to optimize groundwater level monitoring network for existing networks of observation wells where field data is available. It cannot be useful where field data is completely missing. Similarly, other optimization approaches such as SVM, ANN, MSN etc. may not be useful in absence of GWLs/field data. However, entropy is an efficient approach for assessment and optimization of existing GWLMN [98]. This study was conducted in the Kodanagar basin, India which shows that the entropy theory can be applied successfully in the discrete type of groundwater monitoring networks.
Additionally, some of the hybrid approaches such as multicriteria analysis ([114];[86]) show advantage over other approaches. For instance, priority zones demarcated for adding new observation wells in hybrid approach generates the advantage that it does not use GWLs data as input even in absence of GWL data. The priority zones for monitoring can be demarcated as a result. Singh and Katpatal [102] employed new method to demarcate the priority zone using MODIS NDVI data and the results were validated using the field data generated from the multicriteria analysis. Similar type of analysis was also performed by some researchers such as Hosseini and Kerachian [101]; Uddameri and Andruss [99], who have shown that the combination of multi-criteria analysis with suitable optimization approach yields better reliable results. Some of the salient features, advantages and disadvantages of utilizing specific monitoring techniques have been described in Table 4 and Table 5 .

\section{Recent technology advancements and future challenges to groundwater monitoring}

Before the 1980s, most of the designed GWLMNs were based on hydrogeologic approaches. With the advancement of statistical approaches, geostatistical methods were commonly used to design GWLMNs. It appears that after 2010, the trends began shifting towards using geoinformatics-based MCDM approaches to create multi-criteria/objective groundwater networks. However, the evolution of GRACE data in recent years has changed the trends to estimate and quantify groundwater resources, especially at large scales ( $>$ $200,000 \mathrm{~km}^{2}$ ).

The GRACE satellite was launched by NASA in 2002 . Several studies have been reported in recent years that estimate the impacts of changes in groundwater storage due to natural and anthropogenic factors. These studies reflect the effects of changes in groundwater storage on different hydrological-based phenomenon, such as drought [124], climate change ([125]; [126]), groundwater change in large irrigation regions [127], evapotranspiration [128], runoff [129], and land subsidence [130]. However, validations of these studies were based on the groundwater level data obtained from the field.

A major advantage of GRACE data is that they provide spatial and temporal information about groundwater in every part of the world, even in locations where GWLMNs are sparse or absent [131]. GRACE data has been proven to be efficient for large-scale hydrological applications. Low spatial resolution is the major limitation of GRACE data. Despite the fact that several GRACE applications have appeared in recent years, it has not been widely used by water resource managers. Conversely, most of the agricultural and water resource management studies require higher accuracy. For example, it is not feasible to plan and manage groundwater resources at micro watershed scales $\left(<300 \mathrm{~km}^{2}\right)$ using GRACE data. Moreover, GRACE was launched in 2002, but climate change studies require continuous and longterm groundwater data. It has also been observed that GRACE has not been directly used to design GWLMNs. Hence, the monitoring of the groundwater level using the OW network has remained significant for the assessment and estimation of groundwater resources. Considering the future scenario, the focus should be on decreasing the uncertainty of the assessments and increasing the spatial resolution of the GRACE satellite data. Research into solving these problems is already in progress. 
In addition, other remote sensing and airborne techniques to investigate groundwater have also appeared in recent years [132]. For example, InSAR [133], aerial thermal infrared imaging [134], and MODIS [135] have been utilized for groundwater studies. To investigate spatiotemporal patterns over large areas, remote sensing data are very useful. On the other hand, airborne technologies are not feasible for largescale investigations. Unfortunately, there is still considerable uncertainty with regard to groundwater assessments using remote sensing techniques.

There are numerous ground-based tools/approaches available that can be utilized to improve the monitoring and measurement of groundwater in the field. Geophysical methods such as electrical resistivity and ground penetrating radar are useful for quantifying groundwater resources and identifying the subsurface properties of a material. Gravity meters are also advantageous in assessing the changes in groundwater storage and variations in the water table. However, long-term and continuous records are not available for large areas. These methods have been mostly used for very specific purposes and have been restricted to small application areas. Yet, these methods have not been widely applied to monitor and map groundwater levels. The most direct and accurate measurements of groundwater level are obtained from field-based networks of observation wells. Groundwater investigations using observation well networks can be used for small to very large areas. Future work may focus more on (1) the assessment of existing GWLMNs, (2) the design/redesign of GWLMNs and (3) the implementation of an integrated monitoring design for the evaluation of surface and groundwater resources using field and remotely sensed data.

\section{Conclusions}

The present study addresses the historical significance, objectives, previous research outcomes, design techniques, recent studies and future challenges regarding GWLMNs. Peer-reviewed journals, conferences, and international programs indicate that the interest of scientific investigations has gradually grown towards the analysis and design of GWLMNs over the last three decades. However, less attention has been paid to GWLMNs compared to groundwater quality monitoring networks. This review gives an insight of monitoring design and identifies the tradeoff between old and new approaches.

In the literature review, historical details of the GWLMNs in selected countries were briefly summarized. It has been revealed that continuous and long-term GWLMN data are highly uncertain or limited. In many countries, less consideration has been given to assessing and redesigning of the existing networks. The frequency of GWL measurements is also a major concern because the frequency of observation is directly related to monitoring objectives (quantitative assessment, GWL fluctuation, GW-SW interaction, climate change, etc.). Long-term monitoring of GWL allows practitioners and other stakeholders to develop an efficient groundwater management plan that further restricts or minimizes ill effects, such as excessive withdrawals and land subsidence. Consequently, the system may facilitate a better understanding of the complex hydrologic system and climate change variables that influence GWLs. Therefore, constant monitoring of the groundwater level is important for continuous evaluation and sustainable management of groundwater resources.
Statistical-based interpolation techniques such as geostatistical methods have been widely used for optimizing GWLMNs. In recent years, the entropy theory has also been applied to assess and redesign groundwater quality and surface water monitoring networks. With significant improvement in geo-informatics technology over the last two decades, hybrid methods, such as MCA, have been applied for designing monitoring networks in association with different statistical methods and optimization algorithms. The major advantage of using a hybrid method is that it can be applied to design monitoring networks in complex aquifer systems. In addition, this approach is feasible and can be applied to small as well as large areas. Most of the previous design practices considered only single variable parameters (observation wells) to design the monitoring network whereas the new approaches utilize multiple parameters to design the GWLMN. This information is very significant for hydrologists and decision makers to improve or redesign the existing GWLMN.

Recent technological advancements have gradually shifted the need for manual measurements of field data to automated recording systems. Remotely sensed data such as GRACE allow for the systematic collection of spatiotemporal groundwater storage trends; however, its temporal and spatial resolution must be improved to make the measurements available at a larger scale. Conjunctive use of data from field observations and remotely sensed (GRACE and MODIS) datasets can be included in design of GWLMN.

Presently, hydrologist and water resources managers make use of groundwater level monitoring networks to estimate groundwater resources in space and time. Groundwater information is assessed on annual, six monthly, quarterly, monthly basis etc. This assessment of GW resources is based on the information obtained from the networks of observation wells. On the contrary, GWLMN is not assessed and the basis for selecting the locations of observation wells is unclear.

Based on the review of research articles and analysis of different methodologies, the following recommendations may be proposed in relation to GWLMNs to ensure better understanding and quantification of groundwater resources for decision-making purposes.

- It is strongly recommended that systematic groundwater monitoring systems should be established to ensure continuous assessment of groundwater resource.

- It is necessary to revise and design an effective monitoring network system that provide a common platform for consistent data collection systems and a collective data-sharing policy and minimizes the long-term efforts.

- It was also observed that GWLMNs are designed using historical groundwater level records only, but it is essential to include the hydrogeological properties of aquifers and other controlling factors in the analysis during the design of GWLMNs.

- It is also needed to enhance the understanding of the combined behavior of the climate and groundwater level change. In addition to having an isolated groundwater or stream flow monitoring network system, more attention should be given to the design of 'coupled GW-SW monitoring networks'. The focus should be given to the design of an integrated monitoring network system (GW-SW) to measure the adverse effects of natural and anthropogenic 
activities such as earthquake variations, land subsidence, climate change, and seawater intrusion given the recent anthropogenic impacts.

- In order to increase the monitoring efficiency on the field, monitoring frequencies have to be increased at certain locations with complex aquifer systems.

- In addition to groundwater resource assessment, groundwater-monitoring assessment must be incorporated by the hydrologists and decision makers and other stakeholders.

- Hybrid approaches such as the combination of optimization methods and GIS can be adopted to design effective and efficient monitoring network.
As these hybrid approaches in GIS environment consider all the hydrological and anthropogenic parameters in the design of a GWLMN.

Hence, it can be inferred that more research and attention are required in parallel to current policy and implementation of water resources project, with a focus to enhance the monitoring networks.

This is an Open Access article distributed under the terms of the Creative Commons Attribution License

\section{References}

1. M.J. Halverson, S.W. Fleming, "Complex network theory, streamflow, and hydrometric monitoring system design", Hydrol Earth Syst Sci, Vol. No.19, No.7, pp. 3301-3318, (2015)

2. https://iah.org/wp-content/../IAH-Global-Change-Groundwater-14June-2016.pdf.

3. Jousma G, Roelofsen FJ (2004) https://www.unigrac.org/resource/world-wide-inventory-groundwater-monitoring.

4. C. Kikuchi, "Toward Increased Use of Data Worth Analyses in Groundwater Studies." Groundwater, Vol. 55, No.5, pp. 670-673, (2017).

5. S.H. Ahmadi and A. Sedghamiz, "Geostatistical analysis of spatial and temporal variations of groundwater level", Environ. Monit. Asses. Vol.129, No.6, pp. 277-294, (2007).

6. http://www.un-igrac.org/download/file/fid/278.

7. A.K. Mishra, P. Coulibaly, "Developments in hydrometric network design: a review." Rev Geophys, Vol. 47, No.2, RG2001, (2009).

8. R.S. Pyrce, "Review and Analysis of Stream Gauge Networks for the Ontario Stream Gauge Rehabilitation Project." Watershed Science Centre, Trent University, Peterborough, Ontario, Canada, (2004).

9. H.A. Loaiciga, R.J. Charbeneau, L.G. Everett, G.E. Fogg, B.F. Hobbs, S. Rouhani, "Review of ground-water quality monitoring network design.” J Hydraul Eng, Vol. 118, No.1, pp.11-37, (1992).

10. N.B. Harmancioglu, V.P. Singh, N. Alpaslan, "Versatile uses of the entropy concept in water resources", Entropy and energy dissipation in water resources, V. P. Singh and M. Fiorentino, ed., Kluwer, Dordrecht, Netherlands, Vol. 9, pp. 91-118. (1992)

11. Y. Zhang, G. Pinder, G.S. Herrera "Least cost design of groundwater quality monitoring networks." Water Resour Res, Vol. 41, No.8, p.W08412, (2005).

12. K. Ammar, A. Khalil, M. McKee, and J. Kaluarachchi, "Bayesian deduction for redundancy detection in groundwater quality monitoring networks", Water Resour Res, Vol.44, No.8, W08412, (2008).

13. H.J. Peters, "Criteria for groundwater level data networks for hydrologic and modeling purposes." Water Resour Res,Vol. 8, No.1, pp. 194-200, (1972).

14. R.C. Heath, "Design of ground-water level observation-well programs", Ground Water, Vol. 14, No.2, pp. 71-77, (1976)

15. J.P. Hughes, D.P. Lettenmaier, "Data requirements for kriging: Estimation and network design", Water Resour Res Vol. 17,No.6, pp.1641-1650, (1981)

16. M. Sophocleous, J.E. Paschetto, R.A. Olea, "Ground-Water Network Design for Northwest Kansas, Using the Theory of Regionalized Variables." Ground Water, Vol. 20, No.1, pp. 48-58, (1982).

17. R.A. Olea, "Sampling design optimization for spatial functions." Mathematical Geology, Vol. 16 No.4, pp.369-392, (1984).

18. F. Szidarovszky, "Optimal observation network in geostatistics and underground hydrology." App Math Modelling, Vol. 7, No.1, pp.25-32, (1983).

19. I. Bogardi, A. Bardossy, "Multicriterion network design using geostatistics", Water Resour Res Vol. 21, No.2, pp. 199-208, (1985).

20. T. Gleeson, Y. Wada, M.F.P. Bierkens, L.P.H. van Beek, "Water balance of global aquifers revealed by groundwater footprint", Nature, Vol. 488, pp.197-200, (2012)
21. L.F. Jørgensen, J. Stockmarr, "Groundwater monitoring in Denmark: characteristics, perspectives and comparison with other countries". Hydrogeol Journal, Vol.17, No.4, pp.827-842. (2009)

22. Y.B. Katpatal, A.M. Pophare, B.R. Lamsoge, "A groundwater flow model for overexploited basaltic aquifer and Bazada formation in India." Environ Earth Sci, Vol. 72, No.11, pp. 4413-4425, (2014).

23. R.G. Taylor et al., "Groundwater and climate change." Nature Clim Change, Vol. 3, pp.322-329, (2013).

24. C.K. Singh, Y.B., Katpatal, "Effect of global climate change on groundwater resources using geostatistics and linear regression method." Climate Change, Vol.1, pp.491-497, (2015).

25. B.D. Smerdon "A synopsis of climate change effects on groundwater recharge." J Hydrol, Vol. 555, pp.125-128, (2017).

26. R. Ojha, S. Pathak, P.K. Bhunya, S.K. Jain, A.J. Adeloye, "Change Pattern and its Effect on Hydrologic Cycle: A Review." Sustainable water resources management, pp.293-316, (2017)

27. B. Kløve et al., "Climate change impacts on groundwater and dependent ecosystems." J Hydrol. Vol. 518, No.B-10, pp. 250-266, (2014).

28. Y. Subash, M. Sekhar, S.K. Tomer, S.K. Sharma, "A Framework for Assessment of Climate Change Impacts on Groundwater System Formations." Sustainable water resources management, pp. 375397, (2017).

29. C. Tague, G. Grant, M. Farrell, J. Choate, A. Jefferson, "Deep groundwater mediates stream flow response to climate warming in the Oregon Cascades." Clim Change, Vol. 86, No.1-2, pp,189-210, (2008).

30. A.J.M. Kuss, J.J., Gurdak, "Groundwater level response in U.S. principal aquifers to ENSO, NAO, PDO, and AMO.” J Hydrol., Vol. 519, No.B-27, pp.1939-1952, (2014).

31. T. Meixner, A.H. Manning, D.A. Stonestrom, D.M. Allen, H. Ajami, K.W. Blasch, A.E. Brookfield, C.L. Castro, J.F. Clark, D.J. Gochis, A.L. Flint, K.L. Neff, R. Niraula, M. Rodell, B.R. Scanlon, K. Singha, M.A. Walvoord, "Implications of projected climate change for groundwater recharge in the western United States.” J Hydrol, Vol. 534, pp. 124-138, (2016).

32. C. Moeck, P. Brunner, D. Hunkeler, "The influence of model structure on groundwater recharge rates in climate-change impact studies." Hydrogeol J, Vol. 24, No.5, pp.1171-1184, (2016).

33. Chang et al., "Impacts of Climate Change and Urbanization on Groundwater Resources in a Barrier Island", J Environ Eng, Vol.142, No.12, D4016001, (2016)

34. P.H. Kirshen, "Potential impacts of global warming on groundwater in eastern Massachusetts." J Water Resour Plann Manage, Vol. 128, No.3, pp. 216-226, (2002).

35. http://www.energy.ca.gov/2008publications/CEC-500-2008006/CEC-500-2008 006.PDF

36. I.P. Holman, D.M. Allen, M.O. Cuthbert, P. Goderniaux, "Towards best practice for assessing the impacts of climate change on groundwater", Hydrogeol J., Vol.20, No.1, pp.1-4. (2012)

37. Z.W. Kundzewicz, D. Gerten, "Grand challenges related to assessment of climate change impacts on freshwater resources." J Hydrol Eng, Vol. 20, No.1, A4014011, (2015).

38. F.D. Tillman, S. Gangopadhyay, T. Pruitt, "Changes in groundwater recharge under projected climate in the upper Colorado River basin.” Geophys Res Lett, Vol. 43, No.13, pp. 6968-6974, (2016). 
39. L. Huang, G. Zeng, J. Liang, S. Hua "Combined Impacts of Land Use and Climate Change in the Modeling of Future Groundwater Vulnerability", J Hydrol Eng, Vol.22, No.7, 05017007, (2017)

40. G.H.P. Oude Essink, E.S. van Baaren, P.G.B. de Louw, "Effects of climate change on coastal groundwater systems: a modeling study in the Netherlands." Water Resour Res, Vol.46, No.10, (2010).

41. J. Margat, J. van der Gun, "Groundwater around the World: A Geographic Synopsis.” CRC Press/Balkema. Leiden, (2013).

42. M. Dudley-Southern, A. Binley, "Temporal responses of groundwater-surface water exchange to successive storm events", Water Resour Res, Vol.51, No.2, pp.1112-1126, (2015)

43. https://publications.csiro.au/rpr/download?pid=csiro:EP125221\&ds id=DS6.

44. S. Krause, A. Bronstert, E. Zehe, "Groundwater-surface water interactions in a North German lowland floodplain - Implications for the river discharge dynamics and riparian water balance." J Hydrol, Vol. 347, No.3-4, pp.404-417, (2007).

45. D. Kaplan, R. Muñoz-Carpena, "Complementary effects of surface water and groundwater on soil moisture dynamics in a degraded coastal floodplain forest." J Hydrol, Vol. 398, No.3-4, pp. 21-34, (2011).

46. N. Maier, L. Breuer, P. Kraft, "Prediction and uncertainty analysis of a parsimonious floodplain surface water-groundwater interaction model." Water Resour Res, Vol. 53, No.9, pp.7678-7695, (2017).

47. M. Sulis, C. Paniconi, C. Rivard, R. Harvey, D. Chaumont, "Assessment of climate change impacts at the catchment scale with a detailed hydrological model of surface-subsurface interactions and comparison with a land surface model." Water Resour Res, Vol.47, No.1, p.W01513, (2011).

48. M. Larocque, S. Broda, "Groundwater-surface water interactions in Canada." Canadian Water Resources Journal/Revue canadienne des ressourceshydriques, Vol. 41, No.4, pp. 451-454, (2016).

49. K. Rugel, S.W. Golladay, C.R. Jackson, T.C. Rasmussen, "Delineating groundwater/surface water interaction in a karst watershed: Lower Flint River Basin, southwestern Georgia, USA." J Hydrol, Vol. 5, pp. 1-19, (2016).

50. I. Jolly, K. McEwan, K. Holland, “A review of groundwater- surface water interactions in arid/semi-arid wetlands and the consequences for wetland ecology". Ecohydrol, Vol. 1, No.1, pp. 43-58. (2008)

51. B. Wu, Y. Zheng, X. Wu, Y. Tian, F. Han, J. Liu, C. Zheng, "Optimizing water resources management in large river basins with integrated surface water-groundwater modeling: A surrogate-based approach." Water Resour Res, Vol. 51, No.4, pp. 2153-2173, (2015).

52. J.L. Arumí, D. Rivera, E. Holzapfel, P. Boochs, M. Billib, A. Fernald, "Effect of the irrigation canal network on surface and groundwater interactions in the lower valley of the Cachapoal River, Chile", Chilean journal of agricultural research, Vol.69, No.1, pp.12-20, (2009).

53. R. Barthel, S. Banzhaf, "Groundwater and Surface Water Interaction at the Regional-scale - A Review with Focus on Regional Integrated Models", Water Resour Manage Vol. 30, No.1, pp. 1-32. (2016)

54. A. Bárdossy, S.K. Singh, "Regionalization of hydrological model parameters using data depth", Hydrol Res., Vol. 42, No.5, pp. 356371, (2011)

55. Brownbill RJ, Lamontagne S, Williams RM, Cook PG, Simmons CT, Merrick N (2011) Interconnection of surface and groundwater systems - river losses from losing-disconnected streams. Technical final report, June 2011, NSW Office of Water, Sydney NOW 11 187.1

56. https://www.eolss.net/Sample-Chapters/C07/E2-02-01-06.pdf.

57. P.G. Brunner, and C.T. Cook, "Simmons Disconnected Surface Water and Groundwater: From Theory to Practice", Groundwater Vol. 49, No.4, pp. 460-467, (2011)

58. D.L. Galloway, T.J. Burbey, "Review: Regional land subsidence accompanying groundwater extraction", Hydrogeol J., Vol.19, pp.1459-1486, (2011).

59. L.E. Erban, S.M. Gorelick, H.A. Zebker, "Groundwater extraction, land subsidence, and sea-level rise in the Mekong Delta, Vietnam", Environ Res Lett., Vol.9, No.8, pp.1-6, (2014)

60. M.M. Miller, M. Shirzaei, "Spatiotemporal characterization of land subsidence and uplift in Phoenix using InSAR time series and wavelet transforms." J Geophys Res Solid Earth, Vol.120, No.18, pp.5822-5842, (2015).

61. Chang et al., "Stochastically Optimal Groundwater Management Considering Land Subsidence", J Water Resour Plann Manage Vol.133, No.6, pp.486-498, (2005)
62. H.J. Chu, C.T. Hsiao, L.C. Chang, "Optimizing Groundwater Supply with Land Subsidence Limit", World Environmental and Water Resources Congress ASCE, (2007).

63. T.J. Kearns, G. Wang, Y. Bao, J. Jiang, D. Lee, "Current Land Subsidence and Groundwater Level Changes in the Houston Metropolitan Area, Texas (2005-2012)." J Surv Eng, Vol. 141, pp, 1-16, (2015).

64. Y. Zhang, H. Gong, Z. Gu, R. Wang, X. Li, W. Zhao, "Characterization of land subsidence induced by groundwater withdrawals in the plain of Beijing city, China." Hydrogeol J, Vol. 22, No.2, pp.397-409, (2013).

65. Y. Zhang, J. Wu, Y. Xue et al., "Land subsidence and uplift due to long-term groundwater extraction and artificial recharge in Shanghai, China." Hydrogeol J, Vol. 23, No.8, pp.1851-1866, (2015).

66. W.H. Lv, L.C. Miao, C.L. Li, "Physical model test of land subsidence caused by groundwater withdrawal." Geo-Frontiers, pp.1623-1630, 10.1061/41165(397)166, (2012).

67. F. Wang, L. Miao, Y. Zhang, "Numerical study on the parameter sensitivity of land subsidence caused by groundwater withdrawal." Geo-Frontiers, pp.1615-1622, (2012).

68. F. Zhou, J. Xu, X. Wang, "Finite Layer Formulations for Land Subsidence due to Groundwater Withdrawal." Int J Geomech, Vol.17 No.11, pp. 04017099, (2017).

69. D.L. Galloway et al., "Preface: land subsidence processes", Hydrogeol J, Vol. 24, No.3 pp.547-550, (2016)

70. C.C. Faunt, M. Sneed, J. Traum, J.T. Brandt, "Water availability and land subsidence in the Central Valley, California, USA", Hydrogeol J., Vol. 24, No.3, pp. 675-684, (2016)

71. C. Li, X. Tang, T. Ma, "Land subsidence caused by groundwater exploitation in the Hangzhou-Jiaxing-Huzhou Plain, China." Hydrogeol J, Vol.14, No.18, pp.1652-1665, (2006).

72. Y.S. Xu, S.L. Shen, Z.Y. Cai, G.Y. Zhou, "The state of land subsidence and prediction approaches due to groundwater withdrawal in China." Nat Hazards, Vol. 45, No.1, pp. 123-135, (2008).

73. P. Teatini, M. Ferronato, G. Gambolati, M. Gonella, "Groundwater pumping and land subsidence in the Emilia-Romagna coastland, Italy: Modeling the past occurrence and the future trend." Water Resour Res, Vol. 42, No.1, p.W01406, (2006).

74. P. Sahu, P.K. Sikdar, "Threat of land subsidence in and around Kolkata City and East Kolkata Wetlands, West Bengal, India.” J Earth Syst Sci, Vol.120, No.3, pp. 435-446, (2011).

75. Esri, ArcGIS 10.4, Esri, Inc., Redlands, CA, (2016)

76. G. Matheron, The theory of regionalized variables and its applications, Cah. Cent. Morphol. Math., Fasc. No. 5, Ecole Natl. Sup. Mines de Paris (E.N.S.M.P.), Paris, p. 211(1971)

77. T.C. Winter, "An approach to the design of statewide or regional groundwater information systems." Water Resour Res, Vol.8, No.1, pp.222-230, (1972).

78. http://secure.sjrwmd.com/technicalreports/TP/SJ2000-1.pdf.

79. M.R. Prakash, V.S. Singh, "Network design for groundwater monitoring-A case study." Environmental Geology, Vol.39,No.6, pp.628-632, (2000).

80. S. Kumar, S.K. Sondhi, V. Phogat, "Network design for groundwater level monitoring in Upper Bari Doab Canal tract, Punjab, India." Irrig and Drain, Vol. 54, No.4, pp. 431-442, (2005).

81. N. Theodossiou, P. Latinopoulos, "Evaluation and optimisation of groundwater observation networks using the kriging methodology." Environmental Modeling and Software, Vol. 21, pp. 991-1000, (2006).

82. Y. Feng-guang, C. Shu-you, L. Xing-nian, Y. Ke-jun, "Design of groundwater level monitoring network with ordinary kriging", J Hydrodyn Vol.20, No.3, pp. 339-346, (2008)

83. I. Triki, Z. Moncef, B.D. Hamed, "A geostatistical approach for groundwater head monitoring network optimisation: case of the Sfax superficial aquifer (Tunisia)." Water and Environment Journal, Vol. 27, No.3, pp. 362-372, (2013).

84. Y. Wu "Optimal design of a groundwater monitoring network in Daqing, China." Environmental Geology, Vol. 45, No.4, pp. 527$535,(2004)$.

85. P. Goovaerts, "Geostatistics for Natural Resources Evaluation”, New York: Oxford University Press, (1997).

86. C.K. Singh, Y.B. Katpatal "A GIS based Design of Groundwater Level Monitoring Network Using Multi-criteria Analysis and Geostatistical Method." Water Resour Manage, Vol. 31, No.13, pp. 4149-4163, (2017 b). 
87. C.E. Shannon "The mathematical theory of communications, I and II.” Bell Syst Tech J, Vol. 27, pp. 379-423 (1948).

88. C.E. Shannon, W. Weaver. "The mathematical theory of communication", Univ. of Illinois Press, Urbana, IL, (1949).

89. V.P. Singh, "Hydrologic synthesis using entropy theory: Review." J Hydrol Eng, Vol.16, No.5, pp.421-433, (2011).

90. J. Keum, K.C. Kornelsen, J.M. Leach, P. Coulibaly, "Entropy Applications to Water Monitoring Network Design: A Review". Entropy, Vol. 19, p.613, (2017).

91. C. Yoo, K. Hyejin, K. Keewook, "Use of a Distance Measure for the Comparison of Unit Hydrographs: Application to the Stream Gauge Network Optimization.” J Hydrol Eng Vol.16, No.11, pp. 880-890, (2011).

92. J.H. Lee, "Determination of Optimal Water Quality Monitoring Points in Sewer Systems using Entropy Theory." Entropy, Vol. 15, pp.3419-3434, (2013).

93. L. Alfonso E. Ridolfi, G.A. Sandra, F. Napolitano and F. Russo, "Ensemble Entropy for Monitoring Network Design", Entropy Vol 16, No.3, pp. 1365-1375, (2014).

94. Y. Mogheir, V.P. Singh, "Application of information theory to groundwater quality monitoring networks." Water Res Manag, Vol.16, No.1, pp. 37-49 (2002).

95. Y. Mogheir, J.L.M.P. De Lima, V.P. Singh, (2005) “Assessment of Informativeness of Groundwater Monitoring in Developing Regions (Gaza Strip Case Study)." Water Res Manag, Vol. 19, No.6, pp. 737-757.

96. C. Yoo, J. Kwangsik, L. Jaeeung, "Evaluation of Rain Gauge Network Using Entropy Theory: Comparison of Mixed and Continuous Distribution Function Applications.” J Hydrol Eng, Vol.13, No.4, pp. 226-235, (2008).

97. N. Vivekanandan, S.K. Roy, A.K. Chavan, "Evaluation of Rain Gauge Network using Maximum Information Minimum Redundancy Theory." IJSRP, Vol.1, No.3, pp. 96-107, (2012)

98. N.C. Mondal, V.P. Singh, "Evaluation of groundwater monitoring network of Kodaganar River basin from Southern India using entropy." Environ Earth Sci, Vol. 66, No.4, pp. 1183-1193, (2012).

99. V. Uddameri, T. Andruss, "A GIS-based multi-criteria decisionmaking approach for establishing a regional-scale groundwater monitoring." Environ Earth Sci, Vol. 71, No.6, pp. 2617-2628, (2014).

100.J.M. Leach, P. Coulibaly, Y. Guo, "Entropy based groundwater monitoring network design considering spatial distribution of annual recharge." Adv Water Resour, Vol. 96, 108-119, (2016).

101.M. Hosseini, R. Kerachian, "A data fusion-based methodology for optimal redesign of groundwater monitoring networks", J Hydrol, Vol. 552, pp.267-282, (2017)

102.C.K. Singh, Y.B., Katpatal, "Evaluating Control of Various Hydrological Factors on Selection of Groundwater Level Monitoring Networks in Irrigated Areas Using Geospatial Approach.” J Irrig Drain Eng, Vol.143, No.8, 05017003, (2017 c).

103.C.K. Singh, Y.B. Katpatal "Optimization of groundwater level monitoring network using GIS-based geostatistical method and multi-parameter analysis: a case study in Wainganga Sub-basin, India." Chin Geogra Sci, Vol. 27, No.2, pp. 201-215, (2017 a).

104.I.L. McHarg, "Design With Nature”, Wiley, New York, (1969).

105.W.H. Wischmeier, D.D. Smith, "Predicting rainfall erosion losses-A guide to conservation planning." U.S. Department of AgricultureAgriculture Handbook 537. U.S. Government Printing Office, Washington, D.C. (1978)

106.R.B. Slack, R. "Welch Soil conservation service runoff curve number estimates from LANDSAT data." Water Resources Bulletin, Vol.16, No.5, pp. 887-893, (1980).

107.A.R. Schmidt, L.S. Weiss, K.A. Oberg, "Geographic estimation of runoff-model parameters." Proc Symp Engrg Hydro ASCE, New York, N.Y., pp. 551-554(1987).

108.http://rdn.bc.ca/cms/wpattachments/wpID3175atID5999.pdf.

109.J. Krishnamurthy, N. V. Kumar, V. Jayaraman, M. Manivel, “An approach to demarcate groundwater potential zone through remote sensing and a geographic information system." Int J Remote Sens, Vol.17, No.10, pp.1867-1884, (1996).

110.L.D. Hopkins. "Methods of generating land suitability maps: A comparative evaluation", J American Institute of Planners, Vol. 43, pp.386-400, (1977)

111.G. Kim, "Integrated Consideration of Quality and Quantity to Determine Regional Groundwater Monitoring Site in South Korea". Water Resour Manage, Vol. 24, No.14, pp. 4009-4032, (2010).
112.Y. Chao, H. Qian, Y. Fang. et al., “Optimum design of groundwater level monitoring network in Yinchuan plain”, Water Resource and Environmental Protection, Vol.1, pp.278-281, (2011)

113.Y. Zhou, D. Dianwei, L. Jiurong, L. Wenpeng "Upgrading a regional groundwater level monitoring network for Beijing Plain, China." Geoscience Frontiers, Vol.4, No.1, pp.127-138, (2013).

114.J.M. Esquivel, P.M. Guillermo, V.E. María, "Groundwater Monitoring Network Design Using GIS and Multicriteria Analysis." Water Resour Manage. Vol. 29, No.9, pp.3175-3194, (2015)

115.S.B. Jawad, A.H. Karam, "Groundwater monitoring network rationalization using statistical analyses of piezometric fluctuation”. Hydrological Sciences Journal, Vol. 33, No.2, pp.181191. (1988)

116.S. Gangopadhyay, A. Das Gupta, M.H. Nachabe, "Evaluation of Ground Water Monitoring Network by Principal Component Analysis", Ground Water, Vol. 39, No.2, pp. 181-191, (2001)

117.T. Asefa, M.W. Kemblowski, G. Urroz, M. McKee, A. Khalil, "Support vectors-based groundwater head observation networks design", Water Resour Res, Vol. 40,No.11, W11509, doi:10.1029/2004WR003304., (2004)

118.L.M. Nunes, M.C. Cunha, L. Ribeiro, “Optimal space-time coverage and exploration costs in groundwater monitoring networks.” Environ Monit Assess, Vol. 93, No.1-3, pp.103-124, (2004).

119.H.E. Júnez-Ferreira, G.S. Herrera, “A geostatistical methodology for the optimal design of space-time hydraulic head monitoring networks and its application to the Valle de Querétaro aquifer." Environ Monit Assess, Vol.185, No.4, pp. 3527-3549, (2013).

120.M. Hussain, K. Fuchs, J. Fank. "Optimization of the groundwater observation well network" "Leibnitzer-Feld". In: Future Groundwater Resources at Risk (ed. by J. Soveri\& T. Suokko) (Proc. Helsinki Conf., 13-16 June 1994), IAHS Publ. no. 222, pp.221-229, (1995)

121.F. Ben-Jemaa, M.A. Marino, H.A. Loaiciga, "Multivariate geostatistical design of groundwater monitoring networks", J Water Resour Plann Manage Vol. 120, No.4, pp.505-522, (1994)

122.J.C. Fisher, "Optimization of Water-level Monitoring Networks in the Eastern Snake River Plain Aquifer Using a Kriging-based Genetic Algorithm Method", US Geological Survey Scientific Investigations Report 2013-5120, p.74, (2013)

123.Y. Ran, X. Li, X. Lu, Y. Lian, "Optimal selection of groundwaterlevel monitoring sites in the Zhangye Basin, Northwest China." J Hydrol, Vol. 525, pp. 209-215, (2015).

124.B. Li, M. Rodell, "Evaluation of a model-based groundwater drought indicator in the conterminous US." J Hydrol, Vol. 526, pp. 78-88, (2015).

125.F.R. Freedman, K.L. Pitts, A.F.C. Bridger, "Evaluation of CMIP climate model hydrological output for the Mississippi River Basin using GRACE satellite observations", J Hydrol., Vol. 519, pp. 3566-3577, (2014)

126.H. Deng, Y. Chen, "Influences of recent climate change and human activities on water storage variations in Central Asia", J Hydrol, Vol. 544, pp.46-57, (2017)

127.Y.Tang, M. Hooshyar, T. Zhu, C. Ringler, A.Y. Sun, Di. Long, D. Wanga, "Reconstructing annual groundwater storage changes in a large-scale irrigation region using GRACE data and Budyko model." J Hydrol Eng, Vol. 551, pp.397-406, (2017).

128.M.M. Billah, J.L. Goodall, U. Narayan, J.T. Reager, V. Lakshmi, J.S. Famiglietti, "A methodology for evaluating evapotranspiration estimates at the watershed scale using GRACE", J Hydrol Vol. 523: pp. 574-586, (2015).

129.E.A. Sproles, S.G. Leibowitz, J.T. Reager., P.J. Wigington Jr, J.S. Famiglietti, S.D. Patil, "GRACE storage-runoff hystereses reveal the dynamics of regional watersheds." Hydrol Earth Syst Sci, Vol.19, No.7, pp.3253-3272, (2015).

130.J.M. Guo, L. Zhou, C. Yao, J. Hu, "Surface Subsidence Analysis by Multi-Temporal InSAR and GRACE: A Case Study in Beijing. Sensors", Vol.16, No.9, p.1495, (2016)

131.Y.B. Katpatal, C. Rishma, C.K. Singh, "Sensitivity of the Gravity Recovery and Climate Experiment (GRACE) to the complexity of aquifer systems for monitoring of groundwater." Hydrogeol Journal. Vol. 26, No.3, pp. 933-943, (2018).

132.T.R. Green, M. Taniguchi, H. Kooi, J.J. Gurdak, DM Allen, KM Hiscock, H Treidel, A Aureli, "Beneath the surface: impacts of climate change on groundwater", J Hydrol, Vol. 405, No.3-4, pp. $532-560,(2011)$ 
133.P. Castellazzi, R. Martel, A. Rivera, J. Huang, P. Goran, A.I. Calderhead, E. Chaussard, J. Garfias, J. Salas, "Groundwater depletion in Central Mexico: use of GRACE and InSAR to support water resources management", Water Resour Res, Vol. 52, No.8, pp. 5985-6003, (2016)

134.http://dx.doi.org/10.3133/ofr20131168.

135.D. Eamus, S. Zolfaghar, R. Villalobos-Vega, J. Cleverly, A. Huete, "Groundwater-dependent ecosystems: recent insights from satellite and field-based studies", Hydrol Earth Syst Sci Vol.19, No.10, pp. 4229-4256, (2015)

136.http://www.cgwb.gov.in/GWAssessment/Review\%20of\%20Interan tional $\% 20$ Practices $\% 20$ on $\% 20$ Assessment $\% 20$ of $\% 20 \mathrm{GW} \% 20 \mathrm{Res}$ ources.pdf.

137.http://www.cgwb.gov.in/GroundWater/GW\%20Monitoring\%20Re port_January\%202016.pdf.

138.J. Liu, C. Zheng, (2016) "Towards Integrated Groundwater Management in China, In: Jakeman, A.J., Barreteau, O., Hunt, R.J., Rinaudo, J.D., Ross, A. (Eds.)," Integrated Groundwater Management. Springer, Cham, pp.455-475.

139.https://groundwaterwatch.usgs.gov/default.asp.

140.M.T. Bhatti, A.A. Anwar, M. Aslam, "Groundwater monitoring and management: Status and options in Pakistan", Computers and Electronics in Agriculture Vol. 135, No.1.,pp.143-153, (2017)

141.M.V. Camp, M. Radfar, K. Martens, K. Walraevens, "Analysis of the groundwater resource decline in an intramountain aquifer system in Central Iran”, Geologica Belgica, Vol. 15, No.3, 176-180, (2012)

142.https://water.fanack.com/iran/water-challenges-of-iran/

143.M. Shamsudduha "Groundwater-fed Irrigation and Drinking Water Supply in Bangladesh: Challenges and Opportunities", In: Zahid,
A., Hassan, M.Q., Islam, R., Samad, Q.A. (Eds.), Adaptation to the Impact of Climate Change on Socio-economic Conditions of Bangladesh. Alumni Association of German Universities in Bangladesh, German Academic Exchange Service (DAAD), Dhaka, pp. 150-169, (2013).

144.http://www.conagua.gob.mx/CONAGUA07/Publicaciones/Publicac iones/EAM2015_ing.pdf.

145.https://www.bgr.bund.de/EN/Themen/Wasser/Projekte/abgeschloss en/TZ/Acsad/Vol_7_fb_pdf.pdf?__blob=publicationFile\&v=2.

146.Y. Oki, S. Hiraga, "Groundwater monitoring of earthquake prediction by an amateur network in Japan." Pure Appl Geophys, Vol. 126, No.2-4, pp. 211-240, (1988).

147.J. Fornés, K Pirarai, "Groundwater in Thailand", Journal of Environmental Science and Engineering. Vol. 3, pp. 304-315, (2014)

148.https://www.eea.europa.eu/publications/92-9167-032-4/download

149.M. Marcaccio, G. Martinelli, "Effects on the groundwater levels of the May-June 2012 Emilia seismic sequence." Annals of Geophysics, Vol. 55, No.4, pp. 811-814, (2012).

150.S.K. Hsu "Plan for a groundwater monitoring network in Taiwan", Hydrogeol J, Vol. 6, 405-415, (1998)

151.https://www.eea.europa.eu/publications/92-9167-0324/page003.htm.

152.J-Y. Lee, K.D. Kwon, "Current Status of Groundwater Monitoring Networks in Korea." Water, Vol. 8, No.4, pp. 1-16, (2016).

153. http://www.onema.fr/EN/EV/publication/SyntheseSIE-N8.pdf. 